https://helda.helsinki.fi

\title{
Experimental evaluation of nutrient limitation of phytoplankton communities in the Gulf of Riga
}

\section{Seppälä, J.}

Elsevier Science B.V.

1999

Seppälä, J. et al. 1999. Experimental evaluation of nutrient limitation of phytoplankton pÿcommunities in the Gulf of Riga. Journal of Marine Systems 23:107 126.

http://hdl.handle.net/1975/215

Downloaded from Helda, University of Helsinki institutional repository.

This is an electronic reprint of the original article.

This reprint may differ from the original in pagination and typographic detail.

Please cite the original version. 


\title{
Experimental evaluation of nutrient limitation of phytoplankton communities in the Gulf of Riga
}

\author{
J. Seppälä ${ }^{\text {a, * }, ~ T . ~ T a m m i n e n ~}{ }^{\text {a }}$, S. Kaitala ${ }^{\text {b,c }}$ \\ ${ }^{a}$ Finnish Environment Institute, PO Box 140, FIN-00251 Helsinki, Finland \\ ${ }^{\mathrm{b}}$ Department of Limnology, PO Box 27, 00014 University of Helsinki, Helsinki, Finland \\ ${ }^{\mathrm{c}}$ Department of Ecology and Systematics, PO Box 7, 00014 University of Helsinki, Helsinki, Finland
}

Received 20 February 1998; accepted 28 August 1998

\begin{abstract}
Phytoplankton nutrient limitation was studied in the Gulf of Riga during spring bloom (April 1995), early summer stage (June 1994), cyanobacterial bloom (July 1994) and post cyanobacterial bloom (August 1993). Each year six factorial nutrient enrichment experiments were carried out in various locations in the Gulf; including outer Irbe Strait, northern Gulf and southern Gulf. The responses of natural phytoplankton communities to the nutrient additions $\left(80 \mu \mathrm{g} \mathrm{NH}_{4}-\mathrm{N} \mathrm{l}^{-1}, 20 \mu \mathrm{g}\right.$ $\mathrm{PO}_{4}-\mathrm{P}^{-1}$ and two levels of combined additions) were followed for 3 days using 61 experimental units. To evaluate the nutrient limitation patterns, time series of chlorophyll $a$ were analysed using polynomial regression models and ranking method, taking advantage of the relatively constant experimental error. Apparent nutrient depletion rates and ratios were estimated, and compared with the changes in particulate nutrient ratios. During the spring diatom bloom in 1995, ambient inorganic nutrient concentrations were still high, and thus phytoplankton biomass did not respond to additions of nutrients. Chlorophyll $a$ specific nutrient depletion rates were low $\left(0.01-0.12 \mu \mathrm{g} \mathrm{N}(\mu \mathrm{g} \mathrm{chl} a)^{-1} \mathrm{~h}^{-1}\right.$ and $0.002-0.016 \mu \mathrm{g} \mathrm{P}(\mu \mathrm{g} \mathrm{chl}$ $a)^{-1} \mathrm{~h}^{-1}$ ) and linear over time, thus also revealing that phytoplankton was not limited by these nutrients in that time. In June 1994, there was an areal shift from N limitation in the outer Irbe Strait towards co-limitation in the southern Gulf. Later in July 1994, during the bloom of $\mathrm{N}$-fixing Aphanizomenon flos-aquae, the $\mathrm{N}$ limitation was obvious for the whole study area. For this period chlorophyll $a$ specific nutrient depletion rates were high $\left(0.36-0.67 \mu \mathrm{g} \mathrm{N}(\mu \mathrm{g} \text { chl } a)^{-1} \mathrm{~h}^{-1}\right.$ and $\left.0.089-0.135 \mu \mathrm{g} \mathrm{P}(\mu \mathrm{g} \mathrm{chl} a)^{-1} \mathrm{~h}^{-1}\right)$, and added nutrients were almost totally depleted during the first light period. After the collapse of cyanobacterial bloom in August 1993, the experiment carried out in the southern Gulf indicated P limitation of phytoplankton. The central Gulf was obviously co-limited, while the area between northern Gulf and outer Irbe Strait was $\mathrm{N}$-limited. Our results indicate that phytoplankton in the Gulf of Riga, earlier considered strictly as P-limited, is at least until late-summer period $\mathrm{N}$ - or co-limited. It seems also obvious that there exists a spatial tendency in the phytoplankton limitation patterns, generally from more P- or co-limited southern Gulf towards more N-limited northern basin. (C) 1999 Elsevier Science B.V. All rights reserved.
\end{abstract}

Keywords: phytoplankton; nutrient limitation; nitrogen; phosphorus; Gulf of Riga

\footnotetext{
* Corresponding author. Fax: +358-9-40300390.

E-mail address: jukka.seppala@vyh.fi (J. Seppälä)
} 


\section{Introduction}

Potential nutrient limitation of phytoplankton has been studied widely, using different approaches, in various sub-basins of the eutrophicated brackish water Baltic Sea. The results indicate general nitrogen limitation in the Baltic Proper and open Gulf of Finland, while Bothnian Bay and parts of the Neva estuary in the eastern Gulf of Finland are apparently phosphorus limited for most of the growth season (e.g., Tamminen et al., 1985; Granéli et al., 1990; Lignell et al., 1992; Kivi et al., 1993; Pitkänen and Tamminen, 1995). Shifts in the nutrient limitation patterns have been noted to follow salinity gradients, seasonal phytoplankton succession and, of course, the changes in the external N/P loading (Granéli et al., 1990; Kivi et al., 1993; Pitkänen and Tamminen, 1995). Also, the differences in methodology can bring about contradictory conclusions.

In the Gulf of Riga, one of the most eutrophicated parts of the Baltic Sea (e.g., Ojaveer, 1995), experimental studies of nutrient limitation of the phytoplankton community have not been carried out before our study. Previously, phytoplankton in the Gulf has been considered strongly phosphorus-limited, as revealed by the inorganic nutrient ratios (Nehring et al., 1987; Yurkovskis et al., 1993). Long-term trends presented by Yurkovskis and Mazmachs (1990; 1996) show an increase of nutrient concentrations in the whole water column during 1970s and 1980s, with an accumulation of nitrate which was about 70 times higher than that of phosphate. Until 1984, surface layer phosphate concentrations were reported to be at the limit of detection from the spring bloom to the late-autumn (Nehring et al., 1987; Astok et al., 1991). The inorganic $\mathrm{N} / \mathrm{P}(\mathrm{w}: \mathrm{w})$ ratio varied from 9 in winter to 22 in summer (Yurkovskis et al., 1993) during 1989, and was thus well above the Redfield ratio of 7.2. The nutrient regime has recently changed (discussed by Yurkovskis and Mazmachs, 1996; Tamminen and Seppälä, 1999), and relatively high phosphate concentrations have been measured during the phytoplankton growth season (Astok et al., 1991; Yurkovskis and Mazmachs, 1996). Decreased inorganic N/P ratios have been measured in 1993-1995 (Yurkovskis and Mazmachs, 1996; Tamminen and Seppälä, 1999). In their recent study, Maestrini et al. (1997) concluded, from the results of algal growth potential bioassays, that the southeastern part of the Gulf, influenced most by river discharge, is P-limited in mid-spring, but turns towards co-limitation or $\mathrm{N}$ limitation in late spring. They found the area outside the river plume to be $\mathrm{N}$-limited throughout the spring and early summer periods. The appearance of the extensive blooms of nitrogen-fixing cyanobacteria in 1990s (Kahru et al., 1994) has been considered as one sign of the change from P limitation towards $\mathrm{N}$ limitation (Balode, 1994).

In the present study, nutrient limitation of phytoplankton in various locations in the Gulf of Riga during different seasonal stages was examined using active manipulations of natural phytoplankton communities by nutrient additions. Factorial nutrient enrichment experiments were analyzed to reveal main characteristics of nutrient limitation patterns. The experimental results of phytoplankton biomass accumulation and nutrient depletion rates and ratios were compared with the ambient nutrient ratios and concentrations. A closer examination of basin-wide variability of different nutrient fractions and ratios, and their consequences for nutrient limitation is presented in a parallel study by Tamminen and Seppälä (1999).

\section{Material and methods}

\subsection{Sampling and analyses}

Nutrient control of phytoplankton was studied in the Gulf of Riga during cruises of R/V Marina in 1993-1995. Factorial nutrient enrichment experiments (Table 1) were carried out at various locations of the Gulf; ranging from the southern Gulf (Stn. 15)

Table 1

$2^{2}$ factorial design with center point replication. Nutrients were added at the beginning of the experiment. Unit 1 is a control (Ctrl) without manipulations

\begin{tabular}{lll}
\hline $\begin{array}{l}\text { Experimental } \\
\text { unit }\end{array}$ & $\begin{array}{l}\mathrm{PO}_{4}-\mathrm{P} \\
\left(\mu \mathrm{gl}^{-1}\right)\end{array}$ & $\begin{array}{l}\mathrm{NH}_{4}-\mathrm{N} \\
\left(\mu \mathrm{g}^{-1}\right)\end{array}$ \\
\hline (1) Ctrl & - & - \\
(2) $\mathrm{P}$ & 20 & - \\
(3) $\mathrm{N}$ & - & 80 \\
(4) NP & 20 & 80 \\
(5) $1 / 2 \mathrm{NP}$ & 10 & 40 \\
(6) $1 / 2 \mathrm{NP}$ & 10 & 40
\end{tabular}


to the outer Irbe Strait (Stn. 1; see Fig. 1 and Table 2 ). In the late summer period in 1993, after the cyanobacterial bloom, the experiments were carried out at six different stations to obtain first-hand information of the spatial variability of nutrient limitation patterns. For the latter years three representative stations (Stn. 1, Stn. 5 and Stn. 15 in Fig. 1) were selected, and the study periods included spring bloom (sampled twice in 1995), early summer (1994) and cyanobacterial bloom (1994) stages (Table 2). For the description of general spatial and temporal patterns of phytoplankton, nutrients and hydrography during our study periods, see Seppälä and Balode (1999), Stipa et al. (1999) and Tamminen and Seppälä (1999).

Water for the experiments was taken from the surface layer (combined from vertical series from 0 to $10 \mathrm{~m}$ ) with 5-1 Niskin bottles. Subsamples of 61 were transferred to six polycarbonate bottles. Ammonium and phosphate were added at the beginning of the experiment according to the factorial experimental design (Table 1). Bottles were incubated at deck for 3 days. When needed, experimental units were cooled to in situ temperature by continuous flow of surface water through the incubation rack and at times of full sunshine, the high irradiance was cut off with the help of transparent plastic sheets (transmittance about $70 \%$ ).

Samples for chlorophyll $a$ (chl $a$ ), inorganic $\left(\mathrm{NH}_{4}-\mathrm{N}, \mathrm{NO}_{3}-\mathrm{N}\right.$ and $\left.\mathrm{PO}_{4}-\mathrm{P}\right)$ and particulate nutrient (POC, PON and POP) analyses were taken from the initial untreated sample water (day 0 ) and from

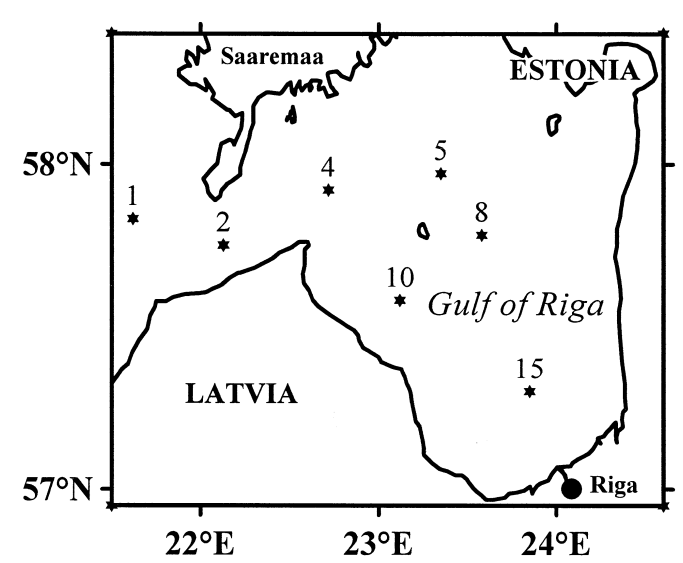

Fig. 1. Sampling stations for the nutrient enrichment experiments. each experimental unit for days $1-3$. Total $\mathrm{N}$ and $\mathrm{P}$ were analysed only from the initial sample water.

For chl $a$, volumes of 50 or $100 \mathrm{ml}$ were filtered onto Whatman GF/F filters, which were subsequently soaked in $96 \%$ ethanol for $24 \mathrm{~h}$ at room temperature. Duplicate measurements were carried out except for days 1 and 2 in the 1994 experiments. Chl $a$ was analysed with a fluorometer (Shimadzu RFPC 5001) calibrated using chl $a$ standard (Sigma) and an extinction coefficient $83.41 \mathrm{~g}^{-1} \mathrm{~cm}^{-1}$ (Wintermans and De Mots, 1965).

All nutrient analyses were carried out as described in Tamminen and Seppälä (1999). In 1993 and 1994, $\mathrm{NO}_{3}-\mathrm{N}$ was not analysed from the experimental units, as the initial concentrations were low $(<8$ and $<3 \mu \mathrm{g} \mathrm{NO} \mathrm{NO}_{3}-\mathrm{N}^{-1}$, respectively) compared to $\mathrm{NH}_{4}-\mathrm{N}$ additions. In 1993, $\mathrm{NH}_{4}-\mathrm{N}$ and $\mathrm{PO}_{4}-\mathrm{P}$ were analysed only from those experimental units the nutrient in question was added. Inorganic nutrient data for E3/93 was not available. Particulate nutrient analyses for day 2 in E1/93 were not performed.

Apparent depletion rates for nutrients were obtained from the difference of inorganic nutrient concentrations between the initial values and sampling values, divided by the incubation time. Depletion rates were calculated from the units with combined nutrient additions using the period nutrients decreased linearly; in 1993, this was 2 days and in 19953 days, while in 1994, nutrients were depleted more rapidly and thus the shortest sampling period of 1 day was used for calculations (except for experiment E1/94, where a 3-day period was suitable). Chl $a$ specific depletion rates were calculated by dividing depletion rates by respective chl $a$ concentrations. For the same time periods, development of particulate nutrient ratios were followed. Trajectories of $\mathrm{N} / \mathrm{P}$ vs. $\mathrm{C} / \mathrm{P}$ were plotted, and the changes were examined in relation to the Redfield nutrient ratio (w:w ratio C/N/P 41:7.2:1; see Fig. 2). As particulate nutrient results were missing for day 2 in E1/93, results from day 3 were used instead. Particulate nutrients were not corrected for detrital and heterotrophic components; thus, the ratios presented do not reflect only phytoplankton but all particulate matter.

Stimulation of $\mathrm{N}$ or $\mathrm{P}$ depletion by the addition of the other was computed by dividing the chl $a$ specific depletion rate from combined addition units (Unit 4) by the chl $a$ specific depletion rate in the 
Table 2

Initial (day 0) conditions of the factorial nutrient enrichment experiments carried out in the Gulf of Riga. For the location of the sampling stations see Fig.1 $\mathrm{TN}=$ total $\mathrm{N}$, TP $=$ total P, A. flos-aquae $=$ Aphanizomenon flos-aquae, T. pseudonana $=$ Thalassiosira pseudonana, $T$. baltica $=$ Thalassiosira baltica, n.d. $=$ not determined

\begin{tabular}{|c|c|c|c|c|c|c|c|c|c|c|c|c|}
\hline $\begin{array}{l}\text { Experiment } \\
\text { code }\end{array}$ & Date & Station & $\begin{array}{l}\text { Salinity } \\
(\% o)\end{array}$ & $\begin{array}{l}\mathrm{DIN} \\
\left(\mu \mathrm{g} \mathrm{1^{-1 } )}\right.\end{array}$ & $\begin{array}{l}\text { DIP } \\
\left(\mu g 1^{-1}\right)\end{array}$ & $\begin{array}{l}\mathrm{TN} \\
\left(\mu g 1^{-1}\right)\end{array}$ & $\begin{array}{l}\mathrm{TP} \\
\left(\mu \mathrm{g} \mathrm{1^{-1 } )}\right.\end{array}$ & $\begin{array}{l}\text { DIN:DIP } \\
(w / w)\end{array}$ & $\begin{array}{l}\text { TN:TP } \\
(w / w)\end{array}$ & $\begin{array}{l}\operatorname{chl} a \\
\left(\mu g 1^{-1}\right)\end{array}$ & $\begin{array}{l}\text { Phytoplankton biomass, } \\
\mathrm{dw}\left(\mathrm{mg} \mathrm{l}^{-1}\right)\end{array}$ & $\begin{array}{l}\text { Main phytoplankton species } \\
\text { (\% of total biomass) }\end{array}$ \\
\hline E1/95 & 20.4 .95 & 1 & 6.89 & 61.9 & 10.1 & 260 & 17.2 & 6.1 & 15.2 & 11.30 & 4.07 & T. baltica (95) \\
\hline $\mathrm{E} 2 / 95$ & 20.4 .95 & 5 & 5.67 & 81.5 & 19.7 & 347 & 27.5 & 4.1 & 12.6 & 21.23 & 6.53 & T. baltica (95) \\
\hline E3/95 & 21.4 .95 & 15 & 4.91 & 114.6 & 11.4 & 548 & 33.2 & 10.0 & 16.5 & 44.10 & 19.32 & T. baltica $(92)$ \\
\hline $\mathrm{E} 4 / 95$ & 24.4 .95 & 1 & 6.56 & 84.8 & 8.5 & 289 & 15.8 & 10.0 & 18.3 & 6.85 & 1.79 & T. baltica $(87)$ \\
\hline E5/95 & 24.4 .95 & 5 & 5.63 & 83.1 & 19 & 376 & 28.9 & 4.4 & 13.0 & 17.99 & 4.68 & T. baltica $(91)$ \\
\hline E6/95 & 26.4 .95 & 15 & 4.89 & 119.2 & 11.1 & 533 & 27.1 & 10.7 & 19.7 & 20.68 & 5.65 & $\begin{array}{l}\text { T. baltica }(67) \text {, } \\
\text { Peridiniella catenata }(32)\end{array}$ \\
\hline E1/94 & 19.6 .94 & 1 & n.d. & 2.3 & 1.4 & 135 & 8.0 & 1.6 & 16.9 & 0.82 & n.d. & n.d. \\
\hline E2/94 & 20.6 .94 & 5 & n.d. & 3.3 & 1.6 & 173 & 13.2 & 2.1 & 13.1 & 3.86 & 0.59 & Gonyaulax triacantha $(21)$ \\
\hline E3/94 & 22.6 .94 & 15 & n.d. & 21.0 & 1.7 & 248 & 17.1 & 12.4 & 14.5 & 4.77 & 0.41 & $\begin{array}{l}\text { T. baltica }(26) \\
\text { A. flos-aquae (18) }\end{array}$ \\
\hline $\mathrm{E} 4 / 94$ & 10.7 .94 & 1 & 6.83 & 1.6 & 2.2 & 202 & 12.1 & 0.7 & 16.7 & 1.75 & 0.43 & $\begin{array}{l}\text { T. pseudonana (58), } \\
\text { Teleaulax sp. (39) }\end{array}$ \\
\hline E5/94 & 11.7 .94 & 5 & 5.60 & 2.8 & 1.8 & 334 & 15.2 & 1.6 & 22.0 & 4.23 & 0.95 & $\begin{array}{l}\text { T. baltica }(31) \\
\text { A. flos-aquae (22) }\end{array}$ \\
\hline E6/94 & 12.7 .94 & 15 & 4.60 & 2.9 & 1.2 & 348 & 20.3 & 2.4 & 17.1 & 7.48 & 3.05 & A. flos-aquae (83) \\
\hline $\mathrm{E} 1 / 93$ & 25.8 .93 & 15 & 5.54 & 45.2 & 2.0 & 434 & 15.6 & 22.6 & 27.8 & 2.98 & 0.60 & Teleaulax sp. (50) \\
\hline $\mathrm{E} 2 / 93$ & 26.8 .93 & 10 & 5.48 & 50.4 & 3.9 & 191 & 10.4 & 12.9 & 18.4 & 2.91 & 0.65 & $\begin{array}{l}\text { Teleaulax sp. (51), } \\
\text { A. flos-aquae (20) }\end{array}$ \\
\hline E3/93 & 26.8 .93 & 8 & 5.48 & 42.8 & 5.2 & 450 & 16.1 & 8.2 & 28.0 & 1.92 & 0.17 & $\begin{array}{l}\text { A. flos-aquae (39), } \\
\text { Dinophysis baltica (23) }\end{array}$ \\
\hline $\mathrm{E} 4 / 93$ & 29.8 .93 & 1 & 7.04 & 12.2 & 2.2 & 215 & 9.7 & 5.5 & 22.2 & 4.70 & 1.39 & $\begin{array}{l}\text { T. pseudonana (43), } \\
\text { Teleaulax sp. (32) }\end{array}$ \\
\hline E5/93 & 30.8 .93 & 2 & 6.37 & 2.6 & 1.3 & 324 & 14.3 & 2.0 & 22.7 & 3.99 & 0.27 & Teleaulax sp. (90) \\
\hline E6/93 & 30.8 .93 & 4 & 5.39 & 38.1 & 3.7 & 463 & 16.4 & 10.3 & 28.2 & 5.24 & 1.03 & $\begin{array}{l}\text { Teleaulax sp. (46), } \\
\text { A. flos-aquae (29) }\end{array}$ \\
\hline
\end{tabular}




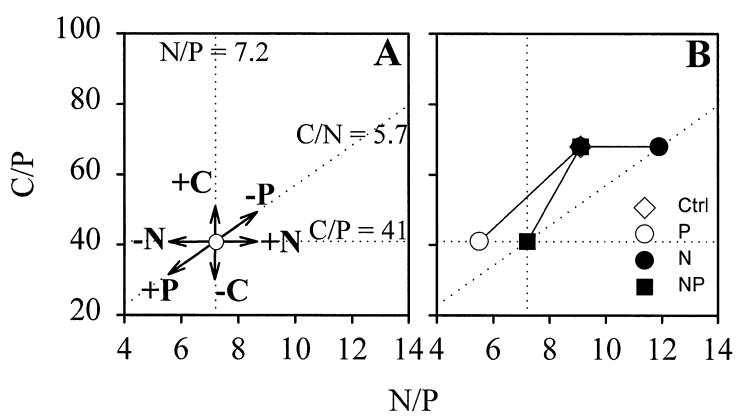

Fig. 2. Scheme for elemental nutrient ratios of particulate matter (A). Dotted lines present the Redfield ratio between two elements, and in the intersection (o) all nutrients are balanced by weight ratio $\mathrm{C} / \mathrm{N} / \mathrm{P} 41 / 7.2 / 1$. The arrows indicate changes in the ratios when surplus or shortage of single nutrient exist, and the remaining two are balanced. The change in natural particulate nutrient ratio due to nutrient manipulations should follow the scheme presented in (B), assuming desire towards the Redfield ratio. All units start from the same initial value (here $\mathrm{N} / \mathrm{P}$ and $\mathrm{C} / \mathrm{P}$ are 9.1 and 68 , respectively, representing average values of the initial phases of all experiments), and in control unit no changes are obvious. In units with single $\mathrm{P}$ and $\mathrm{N}$ addition, $\mathrm{C} / \mathrm{P}$ and $\mathrm{C} / \mathrm{N}$ will move towards balance, respectively, while with combined addition all particulate nutrient ratios should close the Redfield ratios.

unit with single addition (for $\mathrm{N}$, Unit 3 and for $\mathrm{P}$, Unit 2). As in 1995 there was a high ambient $\mathrm{NO}_{3}-\mathrm{N}$ pool, and the $\mathrm{N}$ additions were made as $\mathrm{NH}_{4}-\mathrm{N}$, we were able to compute $\mathrm{N}$ preferences. The preference of a particular nutrient was obtained by dividing its depletion rate by respective total DIN $\left(\mathrm{NO}_{3}-\mathrm{N}+\mathrm{NH}_{4}-\mathrm{N}\right)$ depletion rates.

Additional data of salinity and phytoplankton composition and biomass in the surface layer was obtained as described in Seppälä and Balode (1999). Phytoplankton composition was also analysed for the final stage of experiments E3/95, E4/95 and E5/95.

\subsection{Experimental design and statistical methods}

Nutrient manipulation of experimental units was made according to the two-level factorial design $\left(2^{2}\right)$ with the addition of center point replication (Table 1). Such a design enables us to calculate independent estimate of the experimental error variance and provides information of the existence of quadratic interaction term (Khuri and Cornell, 1987). Repeated measures allow the estimation of time effects (here mean, linear, 2nd order and 3rd order) for the mean and for each manipulation. The complete design matrix $\left(\mathbf{X}_{\mathrm{T}}\right)$ becomes a Kronecker tensor product (kron) of orthogonal polynomial coefficients presenting time $(T)$ and nutrient manipulations $(\mathbf{X})$.

$\mathbf{X}_{\mathrm{T}}=\operatorname{kron}(T, \mathbf{X})$

Then the polynomial regression model can be computed as one-way analysis,

$\mathbf{Y}=\mathbf{b} \mathbf{X}_{\mathrm{T}}+\mathbf{e}$

where $\mathrm{Y}=$ response matrix ( 4 days $\times 6$ units); $\mathrm{b}=$ matrix of regression coefficients; $\mathrm{e}=$ error matrix and the coefficients can be estimated by least squares method using matrix computation (Draper and Smith, 1981)

$\mathbf{b}=\left(\mathbf{X}_{\mathrm{T}}^{\mathrm{t}} \mathbf{X}_{\mathrm{T}}\right)^{-1} \mathbf{X}_{\mathrm{T}}^{\mathrm{t}} \mathbf{Y}$

where $\mathbf{X}_{\mathrm{T}}^{\mathrm{t}}$ stands for the transpose of $\mathrm{X}_{\mathrm{T}}$

Polynomial regression models were calculated for chl $a$ using MATLAB software. From the analysis the mean value and 19 regression coefficients were obtained. Coefficients present the effects of treatments (Control, N, P, NP and 1/2 NP) and the time trends of these (mean, linear, 2nd order and 3rd order). Coefficients were tested using values of $F$ statistics. The sum of squares of individual coefficients $\left(\mathrm{SS}_{\mathrm{b}}\right)$ was calculated as

$\mathrm{SS}_{\mathrm{b}}=\left(\mathbf{X}_{\mathrm{T}}^{\mathrm{t}} \mathbf{X}_{\mathrm{T}}\right)^{-1}\left(\mathbf{X}_{\mathrm{T}}^{\mathrm{t}} \mathbf{Y}\right)^{2}$

and the error sum of squares (SSE) as the difference between sum of squares due to regression and sum of squares within sequence variation of corresponding degree of polynomial (Draper and Smith, 1981). As there were 6 experimental units and 5 coefficients to estimate for each degree, the degrees of freedom for $\mathrm{SSE}$ is 1 . For $\mathrm{SS}_{\mathrm{b}}$, the degrees of freedom is also $1\left(\mathrm{df}=n_{0}-1\right.$, where $n_{0}$ is the number of center point replication, thus here $n_{0}=2$ ) (Khuri and Cornell, 1987). The values for $F$ statistics are obtained by dividing the mean squares of effects $\left(\mathrm{SS}_{\mathrm{b}} / \mathrm{df}\right)$ by the residual mean squares (SSE/df). Regression model for each experiment was made using the coefficients whose value of $F$ exceeded the table value $F_{0.10(1,1)}$. For the 1st experiment in 1993, the center point units were not included; thus, no experi- 
mental error variance was obtained. For this experiment, the significant coefficients for the model were determined with the help of half-normal plots as described by Kivi et al. (1993). The significance of coefficients and predicted responses were examined to reveal the main factors controlling the phytoplankton biomass accumulation.

Apparently for some experiments, the resulting polynomial regression model was unable to reveal all major effects. For comparison, we analysed the whole data set with another approach taking the advantage of the lognormal distribution of the response variables and variance estimate obtained by relatively constant coefficient of variation (T. Andersen, unpublished).

The analysis of 259 duplicate measurements of chl $a$ revealed the heteroscedasticity of the variances, thus the coefficient of variation (CV) was constant throughout the whole scale. Evidently, a similar heteroscedasticity was found for the data from duplicate treatments (1/2 NP-units) (Fig. 3) and the log-deviations between replicate treatments were following closely the normal distribution. Thus, we can consider the obtained average $\mathrm{CV}$ as a reliable estimate of obviously rather constant experimental error. If we assume that variance is independent of the treatment, the average $\mathrm{CV}$ can be used to compute overall variance estimate. After this, we can use simple significance test based on normal probabilities to compare log-transformed chl $a$ results from any two experimental units at certain time. After pairwise comparisons, the responses of experimental units (1/2 NP units not considered here) can be ranked. The maximum number of pairwise comparisons with 4 units will be 6; in most cases, however, 1-3 comparisons were enough to rank units. The comparison-wise risk used in tests was 0.01 , giving an overall experiment-wise risk of about 0.05 . For each experiment, the responses from days 2 and 3 were ranked.
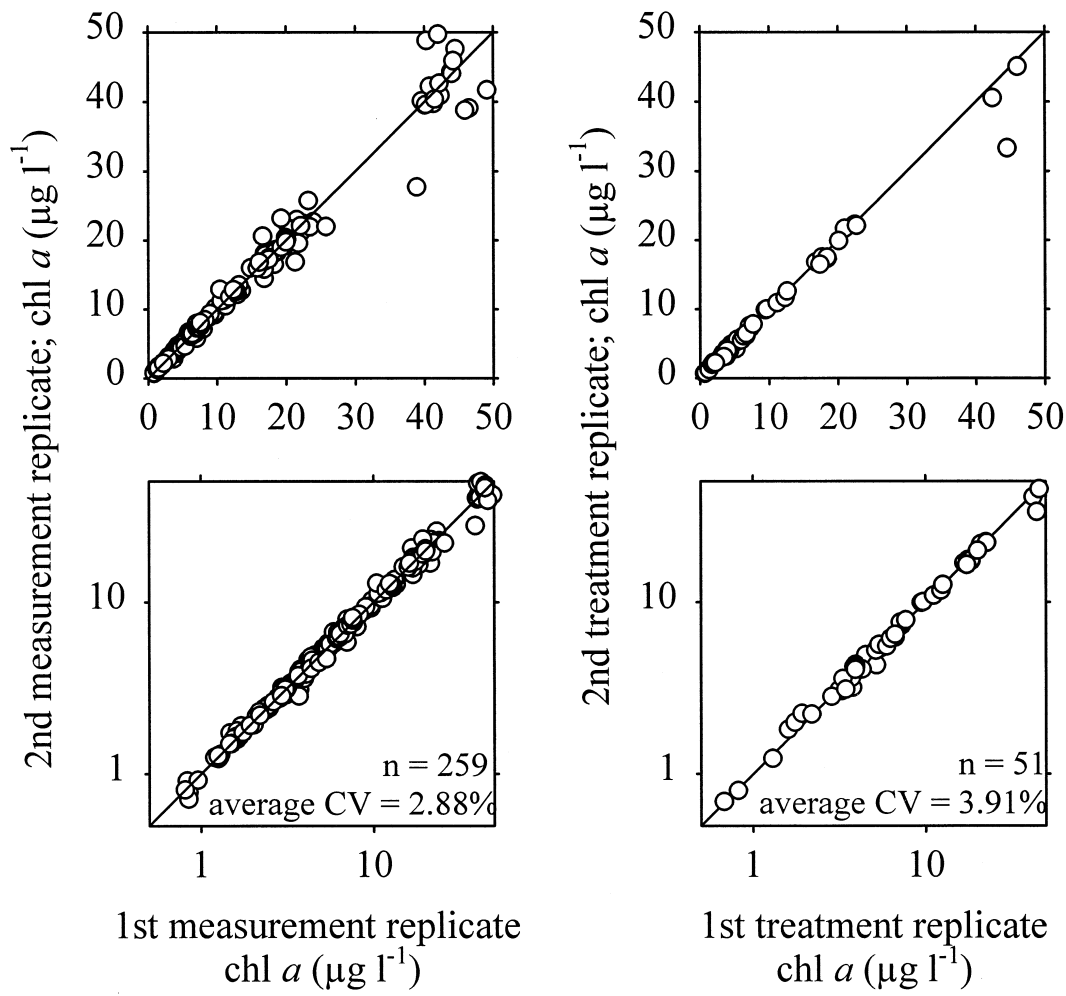

Fig. 3. Replicate chl $a$ measurements on linear and logarithmic scales for (A and C) replicate subsamples $(n=239)$ and for (B and D) replicate experimental units $(n=51)$. 


\section{Results}

\subsection{Spring bloom period in 1995}

Inorganic nutrients accumulated in the water column during wintertime were not fully consumed by the time of our experiments in April 1995 (Table 2). The spring diatom bloom (mainly Thalassiosira baltica) seemed to be, however, already in the declining phase as the phytoplankton biomass and chl $a$ values diminished $15-70 \%$ in our experimental stations between two cruises separated by 4 days. Dissolved inorganic nitrogen, of which $>90 \%$ was $\mathrm{NO}_{3}-\mathrm{N}$, and phosphate pools remained practically unchanged. Inorganic and total $\mathrm{N} / \mathrm{P}$ ratios were lowest in the northern and highest in the southern Gulf experimental stations (see also Tamminen and Seppälä, 1999).

In each of the six experiments, temporal development of chl $a$ in the nutrient enriched units was rather similar to the control unit (Fig. 4). The poly- nomial regression models indicated slight effects of manipulations in four experiments. In E2/95, at the northern Gulf, effects of NP and P additions were, if not clear-cut, at least worth noticing. In the other experiments, most of the variability in chl $a$ values was explained by temporal effects, not by different treatments (Table 3). Pairwise comparisons of responses indicated that there were no differences between treatments, with two exceptions (Table 3). In $\mathrm{E} 5 / 95$, the chl $a$ concentration in the unit with combined nutrient addition exceeded significantly that with single $\mathrm{N}$ addition (though only for day 2), but was not different from the control unit. At the final stage of E6/95, the chl $a$ concentration was actually higher in the control unit than in the NP unit.

The domination of diatom $T$. baltica remained unchanged in the first experiment in the southern Gulf (E3/95) as it contributed $92 \%$ of the total phytoplankton biomass in the beginning of the experiment and $93-94 \%$ in the end, regardless of the
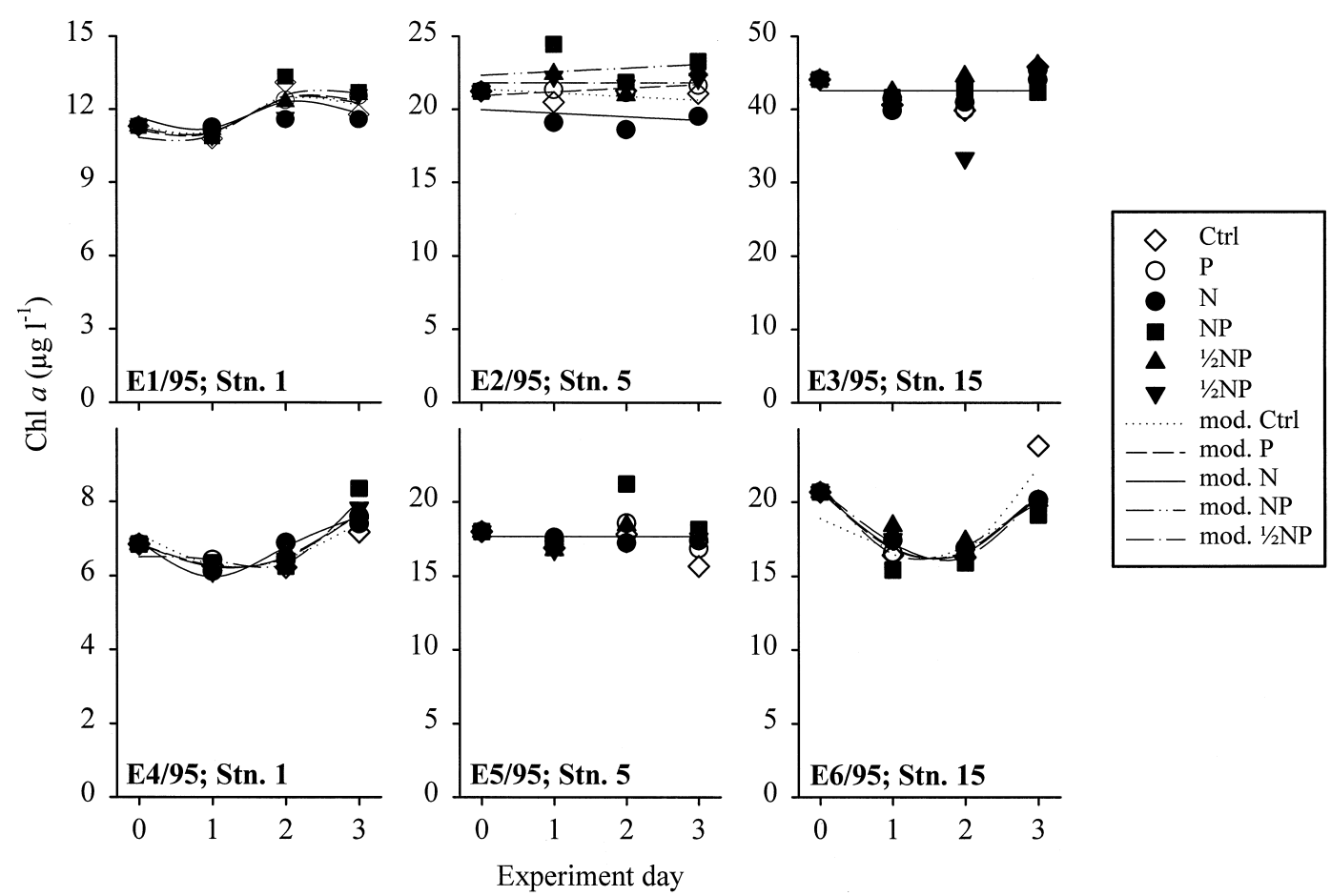

Fig. 4. Temporal development of chl $a$ and simulations (lines) by polynomial regression models in the nutrient enrichment experiments carried out in the Gulf of Riga in spring 1995. For the location of the stations and times for conducting the experiments, see Fig. 1 and Table 2. 
Table 3

Results of the statistical analysis of the factorial nutrient enrichment experiment chl $a$ responses. Major significant effects of the polynomial regression models are indicated for each experiment $\left(n=\right.$ number of regression coefficients used in the model; $r^{2}=$ coefficients of determination). Ranking of chl $a$ responses for experimental days 2 and 3 is based on the pairwise comparisons of log-transformed data for corresponding dates (for details see text). Experimental units are listed in the decreasing order of chl $a$ response. Significant differences $(p<0.05)$ have been indicated by greater-than operator $(>)$ and units with similar responses are underlined. The intersections of two groups are indicated by multiple underlining

\begin{tabular}{|c|c|c|c|c|c|}
\hline \multirow[t]{2}{*}{ experiment } & \multicolumn{3}{|c|}{ regression model } & \multicolumn{2}{|c|}{ ranking after pair-wise comparisons } \\
\hline & $\mathrm{n}$ & $\mathrm{r} 2$ & major responses & day 2 & day 3 \\
\hline E1/95 & 4 & 0.74 & $t, t^{3}$ & NPCPN & NPPCN \\
\hline $\mathrm{E} 2 / 95$ & 4 & 0.65 & $N P, P$ & NPCPN & NPPCN \\
\hline $\mathrm{E} 3 / 95$ & 0 & 0.00 & - & NP NPC & C P N NP \\
\hline $\mathrm{E} 4 / 95$ & 6 & 0.93 & $t^{2}, t$ & NP NPC & NPP NC \\
\hline $\mathrm{E} 5 / 95$ & 0 & 0.00 & - & NPPC N & NP NPC \\
\hline $\mathrm{E} 6 / 95$ & 9 & 0.88 & $t^{2}$ & NPC NP & $\underline{C P N N P}$ \\
\hline E1/94 & 10 & 0.92 & $\mathrm{t}, \mathrm{t}^{2}, \mathrm{~N}$ & NCNPP & $\underline{\mathrm{NPN}}>\underline{\mathrm{PC}}$ \\
\hline $\mathrm{E} 2 / 94$ & 10 & 0.83 & $N, 1 / 2 N P, t^{3}$ & $N P>N>\underline{P C}$ & $N P>N>\underline{P C}$ \\
\hline$E 3 / 94$ & 2 & 0.69 & $t^{2}, t^{3}$ & NPCNP & $N P>\underline{P N C}$ \\
\hline E4/94 & 7 & 0.77 & $\mathrm{~N}, \mathrm{Nt}, \mathrm{NP}$ & $\mathrm{NP}>\mathrm{N}>\underline{\mathrm{CP}}$ & $\mathrm{NP}>\mathrm{N}>\underline{\mathrm{PC}}$ \\
\hline $\mathrm{E} 5 / 94$ & 7 & 0.97 & $\mathrm{t}, \mathrm{N}$ & $\underline{\mathrm{NP} N}>\mathrm{C}>\mathrm{P}$ & $\underline{\mathrm{NPN}}>\underline{\mathrm{CP}}$ \\
\hline $\mathrm{E} 6 / 94$ & 11 & 0.92 & $\mathrm{~N}, \mathrm{t}^{2}, \mathrm{NP}$ & $N P>N>\underline{C P}$ & $\mathrm{NP}>\mathrm{N}>\underline{\mathrm{PC}}$ \\
\hline E1/93 & 9 & 0.83 & $\mathrm{t}, \mathrm{t}^{2}, \mathrm{P}$ & $\underline{\mathrm{NPP}}>\underline{\mathrm{CN}}$ & $\mathrm{NP}>\mathrm{P}>\underline{\mathrm{NC}}$ \\
\hline E2/93 & 11 & 0.97 & $t, t^{2}$ & NP N C P & $N P>\underline{N C P}$ \\
\hline$E 3 / 93$ & 10 & 0.95 & $\mathrm{t}, \mathrm{Nt}, 1 / 2 \mathrm{NPt}^{2}$ & NP N P C & $N P>N>\underline{C P}$ \\
\hline $\mathrm{E} 4 / 93$ & 10 & 0.79 & $\mathrm{~N}, \mathrm{t}^{2}, 1 / 2 \mathrm{NPt}^{2}$ & $N P>N>\underline{C P}$ & $N P>N>\underline{C P}$ \\
\hline $\mathrm{E} 5 / 93$ & 18 & 1.00 & $N, t^{2}, N P$ & $N P>N>\underline{P C}$ & $N P>N>\underline{C P}$ \\
\hline E6/93 & 5 & 0.48 & $\mathrm{Nt}, \mathrm{t}, 1 / 2 \mathrm{NPt}$ & NP N P C & $N P>N>P C$ \\
\hline
\end{tabular}

manipulation (data not shown). As an indication of the change in phytoplankton community structure, due to natural succession or bottle effects in the Irbe Strait area and northern Gulf (E4/95 and E5/95), the proportion of $T$. baltica from the total phytoplankton biomass decreased from $87 \%$ to $71-74 \%$ and from $91 \%$ to $81-85 \%$, respectively. This decrease was accompanied with the increase of the dinoflagellate Peridiniella catenata, both in number and proportion from the total biomass (in E4/95, from $9 \%$ of the total phytoplankton biomass in the beginning to $16-22 \%$ in the end and in E5/95 from $5 \%$ to $12-14 \%$, respectively). These changes were not affected by nutrient manipulations.

Nutrient depletion rates were rather constant for the three day period in all experiments. Only in the 
southern Gulf (E3/95 and E6/95; Stn. 15) the initial (0-1 day) nutrient depletion rates were higher than the rates calculated for the whole experiment periods. Also, the highest apparent depletion rates were measured at that station (Fig. 5), but this was due to higher algal biomass. In the experiments $\mathrm{E} 4 / 95$ and $\mathrm{E} 6 / 95$ ambient $\mathrm{PO}_{4}-\mathrm{P}$ was almost exhausted in the control units and in the latter experiment the decrease of $\mathrm{PO}_{4}-\mathrm{P}$ in units with $\mathrm{PO}_{4}-\mathrm{P}$ addition exceeded natural concentration (data not shown). For both cruises, the chl $a$ specific depletion rates were highest in the experiments at the Irbe strait region (E1/95 and E4/95), and lowest in the northern Gulf (E2/95 and E4/95) (Fig. 5). Chl $a$ specific $\mathrm{N}$ and $\mathrm{P}$ depletion rates increased 4.9-8.0and 3.6-4.5-fold, respectively, between two experiments at the same site and consequently inorganic $\mathrm{N} / \mathrm{P}$ depletion ratio (w:w) increased from 3.2-4.7 to 5.1-7.1 (Fig. 5).

When chl $a$ specific depletion rates in combined and single addition units were compared, no P stimu-
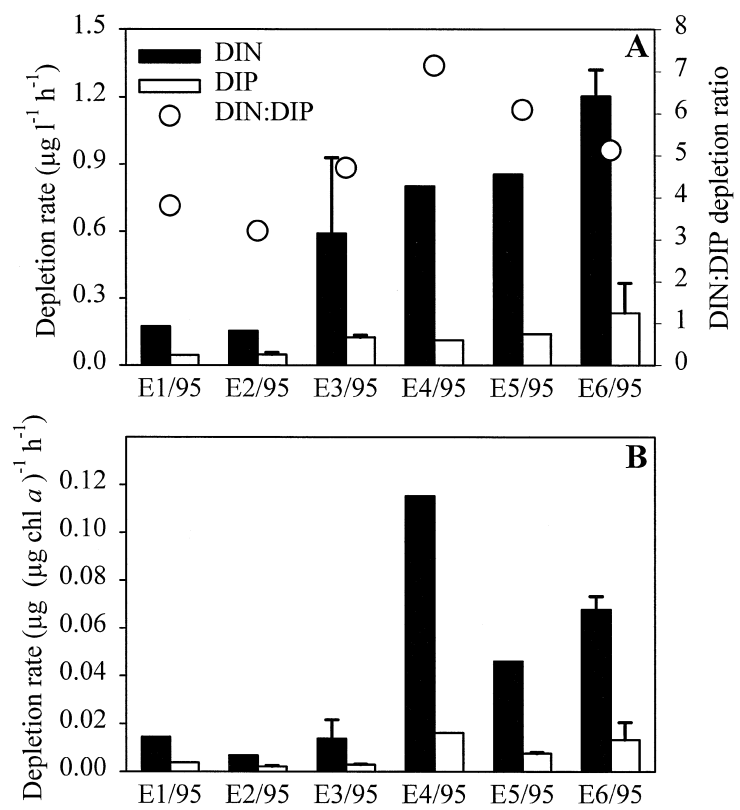

Fig. 5. Apparent depletion rates and ratios (A) and chl $a$ specific depletion rates (B) of ammonium and nitrate (DIN) and phosphate (DIP) in the experimental units with full nutrient additions (Unit 4) in spring 1995. Rates have been calculated from the decrease of inorganic nutrients during the whole experiment period (0-3 days); initial (0-1 day) rates exceeding this are shown as error bars.
Table 4

Stimulation of nutrient (DIN or DIP) depletion by the addition of the other nutrient. Expressed as difference (in \%) of chl $a$ specific depletion rates in unit with combined addition to unit with single addition

\begin{tabular}{|c|c|c|}
\hline Experiment & $\begin{array}{l}\mathrm{N} \text { stimulation } \\
\text { of } \mathrm{P} \text { uptake }(\%)\end{array}$ & $\begin{array}{l}\text { P stimulation } \\
\text { of } \mathrm{N} \text { uptake }(\%)\end{array}$ \\
\hline E1/95 & -20 & -7 \\
\hline E2/95 & 29 & -11 \\
\hline E3/95 & 73 & -15 \\
\hline $\mathrm{E} 4 / 95$ & -2 & -3 \\
\hline E5/95 & 12 & 0 \\
\hline E6/95 & 17 & 4 \\
\hline E1/94 & 1 & -19 \\
\hline E2/94 & -5 & 38 \\
\hline E3/94 & -1 & 11 \\
\hline E4/94 & 59 & 7 \\
\hline E5/94 & 53 & 34 \\
\hline E6/94 & 11 & 88 \\
\hline E1/93 & 42 & 76 \\
\hline E2/93 & 1 & 8 \\
\hline E3/93 & n.d. & n.d. \\
\hline $\mathrm{E} 4 / 93$ & 57 & 35 \\
\hline E5/93 & 437 & 33 \\
\hline E6/93 & 11 & 42 \\
\hline
\end{tabular}

lation of $\mathrm{N}$ depletion was observed (Table 4). Addition of $\mathrm{NH}_{4}-\mathrm{N}$ stimulated $\mathrm{PO}_{4}-\mathrm{P}$ depletion in E2/95 and $\mathrm{E} 3 / 95$ by $29 \%$ and $73 \%$, respectively, while in the other experiments stimulation was not so evident. Phosphate depletion was obviously saturated in the natural conditions, as the depletion rates in units with $\mathrm{PO}_{4}-\mathrm{P}$ addition were similar $(0.88-1.13$-fold $)$ to the rates in control units.

As a sign of $\mathrm{N}$ source preference, in the units with $\mathrm{NH}_{4}-\mathrm{N}$ addition, nitrate depletion rates were lower than in the units without $\mathrm{NH}_{4}-\mathrm{N}$ (data not shown). Ammonium depletion rates were, however, relatively high and the overall $\mathrm{N}$ depletion increased on average $42 \%$ (range $10-99 \%$ ) due to $\mathrm{NH}_{4}-\mathrm{N}$ addition. When both inorganic $\mathrm{N}$ sources were present, 50$100 \%$ of $\mathrm{N}$ was taken up as $\mathrm{NH}_{4}-\mathrm{N}$. Ammonium preference was not constant but increased during the experimental period.

Initial particulate nutrient ratios showed excess of $\mathrm{C}$ and $\mathrm{N}$ relative to $\mathrm{P}$ (Fig. 6, see also Tamminen and Seppälä, 1999). In the first experiment at Irbe Strait, changes of particulate nutrient ratios in all units indicated storage of $\mathrm{P}$ as both $\mathrm{N} / \mathrm{P}$ and $\mathrm{C} / \mathrm{P}$ ratios decreased, but the $\mathrm{C} / \mathrm{N}$ ratio remained rather con- 


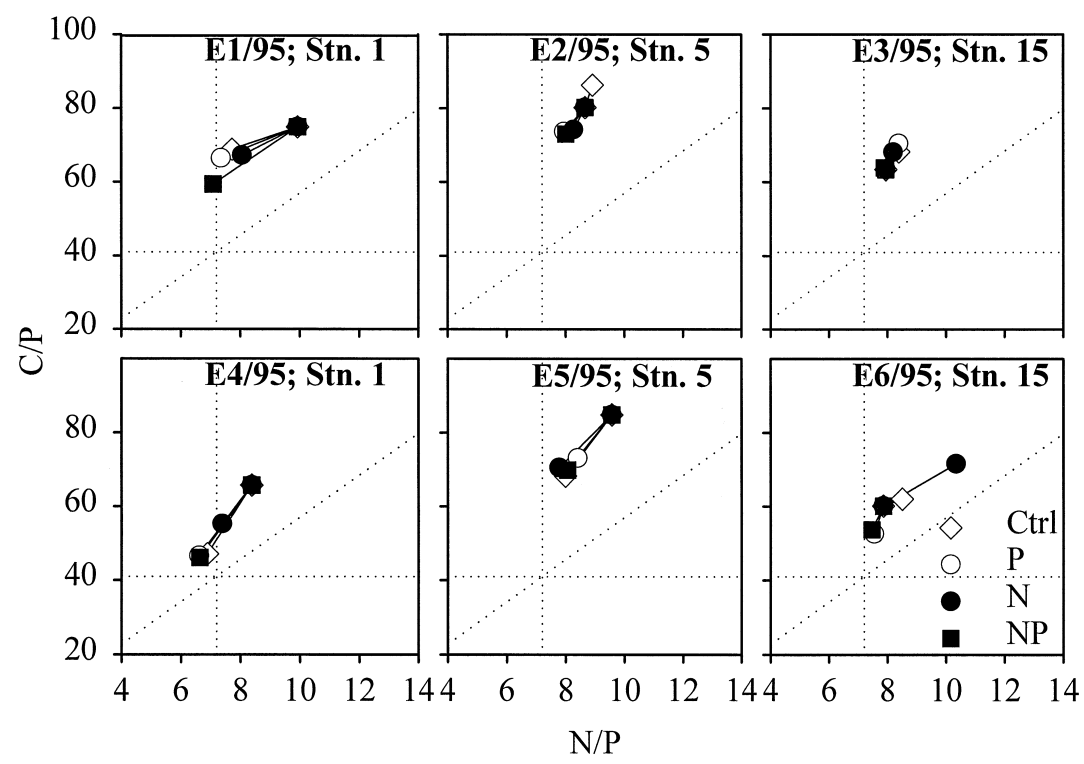

Fig. 6. Trajectories of particulate nutrient ratios in the experiments in spring 1995.
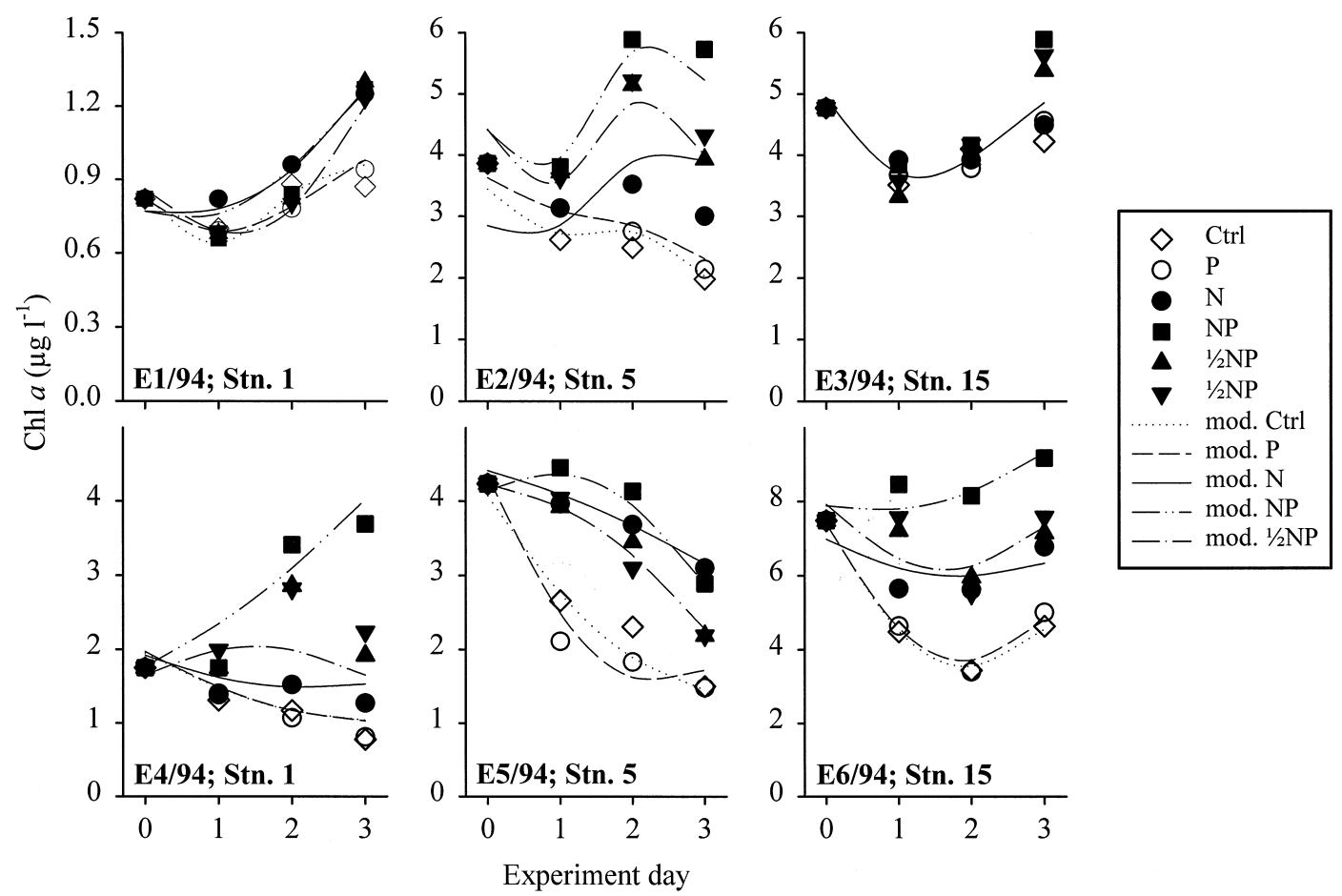

Fig. 7. Temporal development of chl $a$ and simulations (lines) by polynomial regression models in the nutrient enrichment experiments carried out in the Gulf of Riga in mid-June and mid-July in 1994. For the location of the stations and times for conducting the experiments, see Fig. 1 and Table 2. 
stant. Rather similar patterns were noted 4 days later at the same site (E4/95) and also in the northern Gulf (E5/95). In those experiments, however, the $\mathrm{C} / \mathrm{N}$ ratio also slightly decreased. In the latter experiment in the southern Gulf (E6/95), in the unit with single $\mathrm{N}$ addition, particulate matter became P-deficient. In all experiments, the resulting $\mathrm{N} / \mathrm{P}$ ratio (w:w) in the units with combined addition did not fall below 6.5 .

\subsection{Early summer period in 1994}

By mid-June in 1994, the winter reserves of inorganic nutrients were consumed. High ammonium concentrations, elevated probably by increased mixing due strong winds, were, however, found in the southern Gulf (Table 2, see also Tamminen and Seppälä, 1999). Inorganic N/P ratios were low except for the southern Gulf with high ammonium. Phytoplankton biomass was low at Stn. $1(<1 \mu \mathrm{g}$ chl $\left.a 1^{-1}\right)$, and dominated by pico-sized $(<2 \mu \mathrm{m})$ algae. Inside the Gulf higher ( $>3 \mu \mathrm{g}$ chl $\left.a 1^{-1}\right) \mathrm{chl}$ $a$ values were recorded, and the phytoplankton community was characterised by dinoflagellates, cyanobacteria and diatoms (cf. Seppälä and Balode, 1999).

In the experiment at Irbe Strait (E1/94), both regression model and ranking method indicated $\mathrm{N}$ limitation of the phytoplankton, as the chl $a$ response to $\mathrm{N}$ addition was similar to combined addition, and further, addition of $\mathrm{P}$ did not cause any response when compared with the control unit (Fig. 7 and Table 3). $\mathrm{N}$ limitation was also obvious in the northern Gulf (E2/94), although combined addition caused the highest response. In the southern Gulf (E3/94), only combined addition evoked the chl $a$ response, and the phytoplankton community was evidently co-limited. The regression model identified only time trends as significant effects, but the ranking method confirmed that chl $a$ concentration in the combined addition unit was significantly higher than in the single addition or control units at day 3 (Table 3).

Nutrient depletion rates in the Irbe Strait area (E1/94) were lower than in spring 1995, but comparable (for $\mathrm{N}$ depletion) or higher (for $\mathrm{P}$ depletion) when normalized to chl $a$ concentration (Fig. 8). In
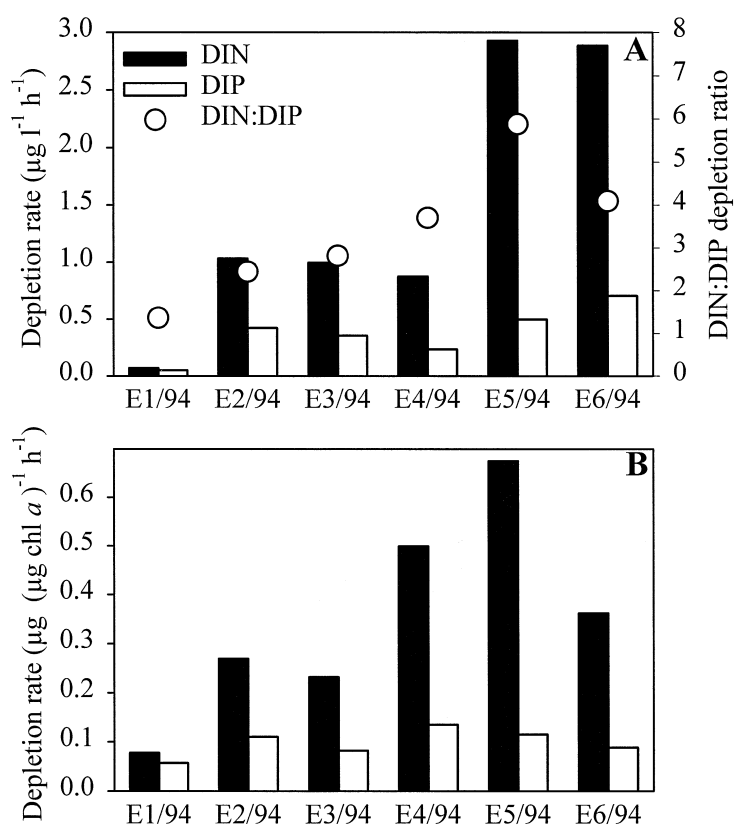

Fig. 8. Apparent depletion rates and ratios (A) and chlorophyll $a$ specific depletion rates (B) of ammonium (DIN) and phosphate (DIP) in the experimental units with full nutrient additions (Unit 4) in mid-June and mid-July in 1995. Rates have been calculated from the decrease of inorganic nutrients during the first experiment day (except for E1/94 whole experiment period).

the other experiments, the depletion rates were higher. $\mathrm{N} / \mathrm{P}$ depletion ratio changed from 1.4 in the Irbe strait (E1/94) to 2.8 in the southern Gulf (E3/94) (Fig. 8). In the experiment at northern Gulf (E2/94), phosphate stimulation of $\mathrm{NH}_{4}-\mathrm{N}$ depletion was clear $(38 \%)$, and practically all of the added $\mathrm{NH}_{4}-\mathrm{N}$ was consumed during the study period in the unit with combined addition, while more than $50 \%$ was left in the unit with single $\mathrm{NH}_{4}-\mathrm{N}$ addition. In the other experiments, stimulations of nutrient depletion were not so evident (Table 4).

In early summer 1994, natural particulate $\mathrm{N} / \mathrm{P}$ ratios were higher than in the spring 1995 (Fig. 9). In all experiments, the ratios moved towards the Redfield ratio in units with $\mathrm{P}$ or combined addition. Addition of $\mathrm{N}$ alone did not affect $\mathrm{C} / \mathrm{N}$ ratios, but decrease of $\mathrm{N} / \mathrm{P}$ ratio, due to relatively higher increase of POP, was observed in two experiments (E1/94 and E3/94). The reason for a such contradictory behavior is not obvious. 


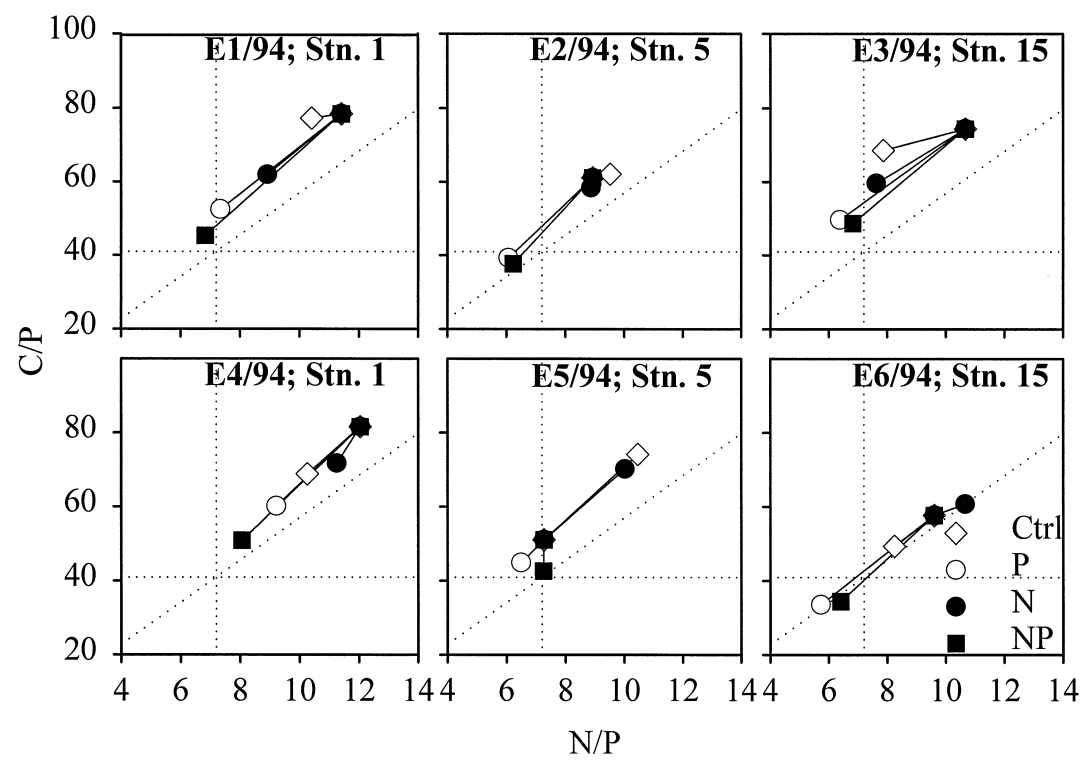

Fig. 9. Trajectories of particulate nutrient ratios in the experiments in summer 1994.

\subsection{Cyanobacterial bloom period in 1994}

The rough weather in June 1994 was followed by calm and warm period leading to formation of secondary thermocline at 3-7 m, and warming up of the surface layer. Inorganic nutrient concentrations were similar or even lower than in mid-June, and inorganic $\mathrm{N} / \mathrm{P}$ ratio had decreased (Table 2). Phytoplankton biomass had increased notably, and the community was dominated by pico-algae in the northern Gulf, while high biomass of filamentous cyanobacteria ( A. flos-aquae) was an important feature in the southern Gulf (see Seppälä and Balode, 1999).

As a general tendency for all experiments, chl $a$ values decreased similarly in the control and $\mathrm{P}$ addition units during the study periods (Fig. 7). In all cases, chl $a$ response to $\mathrm{N}$ addition was significantly higher than in control (Table 3). In the northern Gulf (E4/94), $\mathrm{N}$ was clearly the only limiting nutrient, while in the other two experiments combined addition caused highest responses.

Nutrient depletion rates were still lowest at the Irbe Strait region (E4/94) (Fig. 8). In the other two experiments, $\mathrm{NH}_{4}-\mathrm{N}$ was almost totally depleted during the first day, and thus the values for $\mathrm{N}$ depletion are somewhat underestimated. When nor- malized to chl $a$ concentrations, the $\mathrm{N}$ depletion rate was highest in the experiment at northern Gulf (E5/94), while P depletion was highest at the Irbe Strait (E4/94) (Fig. 8). Generally, depletion of nutrients was faster in mid-July than during previous experiments in mid-June (Fig. 8). At the Irbe Strait (E1/94 vs. E4/94), the chl $a$ specific $\mathrm{N}$ and $\mathrm{P}$ depletion rates increased 6.4- and 2.4-fold, respectively. In the northern (E2/94 vs. E5/94) and southern Gulf (E3/94 vs. E6/94), the increase of chl $a$ specific $\mathrm{N}$ depletion was 2.5- and 1.6-fold, respectively, but not evident for $\mathrm{P}$ depletion. As $\mathrm{N}$ depletion increased relatively more than $\mathrm{P}$ depletion, $\mathrm{N} / \mathrm{P}$ depletion ratio increased at all experiment sites (Fig. 8).

Addition of ammonium stimulated chl $a$ specific $\mathrm{PO}_{4}-\mathrm{P}$ depletion for more than $50 \%$ in the experiments at the Irbe Strait and northern Gulf (E4/94 and E5/94) (Table 4). In contrast, due to addition of phosphate, chl $a$ specific $\mathrm{N}$ depletion almost doubled at the southern Gulf (E6/94). Phosphate stimulation of $\mathrm{N}$ depletion was also evident in E5/94.

In the Irbe Strait area (E4/94), the particulate nutrient ratios were comparable to those observed 4 weeks earlier in mid-June (Fig. 9); also, the changes in the ratios were rather similar, as they moved towards the Redfield ratio in all units. In the northern 
Gulf (E5/94), all ratios were already close to the Redfield ratio, and only very slight changes took place in the units with $\mathrm{P}$ and NP additions. In the units without $\mathrm{P}, \mathrm{N} / \mathrm{P}$ and $\mathrm{C} / \mathrm{P}$ ratios increased markedly. The reasons for the similar changes in these units were different, as in the control unit relatively high decrease of POP took place in the beginning of the experiment, while in the $\mathrm{N}$ unit both POC and PON concentrations increased and POP remained constant. In the southern Gulf (E6/94), $\mathrm{C} / \mathrm{N}$ ratio was close to the Redfield ratio, and was practically unchanged due to nutrient additions. Addition of $\mathrm{P}$ caused significant decrease of both $\mathrm{N} / \mathrm{P}$ and $\mathrm{C} / \mathrm{P}$ ratios.

\subsection{Late summer period in 1993}

Late summer period in 1993 was characterised by windy weather and deep mixing. Plankton community was probably net heterotrophic (cf. Olli and Heiskanen, 1999; Donali et al., 1999). High ammo- nium concentrations prevailed in the whole Gulf, especially in the southern parts, leading to high inorganic $\mathrm{N} / \mathrm{P}$ ratio (Table 2, see also Tamminen and Seppälä, 1999). Phytoplankton biomass and chl $a$ concentrations were highest in the northern Gulf. Roughly $1 / 2$ of the microphytoplankton biomass was due to cryptomonads, mainly Teleaulax sp., while cyanobacteria and small diatoms were also important constituents of the phytoplankton community.

As this was our first study period in the Gulf of Riga, six different locations were chosen for the enrichment experiments to get good view of spatial heterogeneity of the limitation patterns. The first experiment (E1/93) in the southern Gulf indicated P-limitation of phytoplankton community, although combined nutrient addition induced the highest chl $a$ response (Fig. 10 and Table 3). In the central Gulf (E2/93 at Stn. 10), single nutrient additions had no effect, but especially the pairwise comparison method revealed that the response from NP addition was

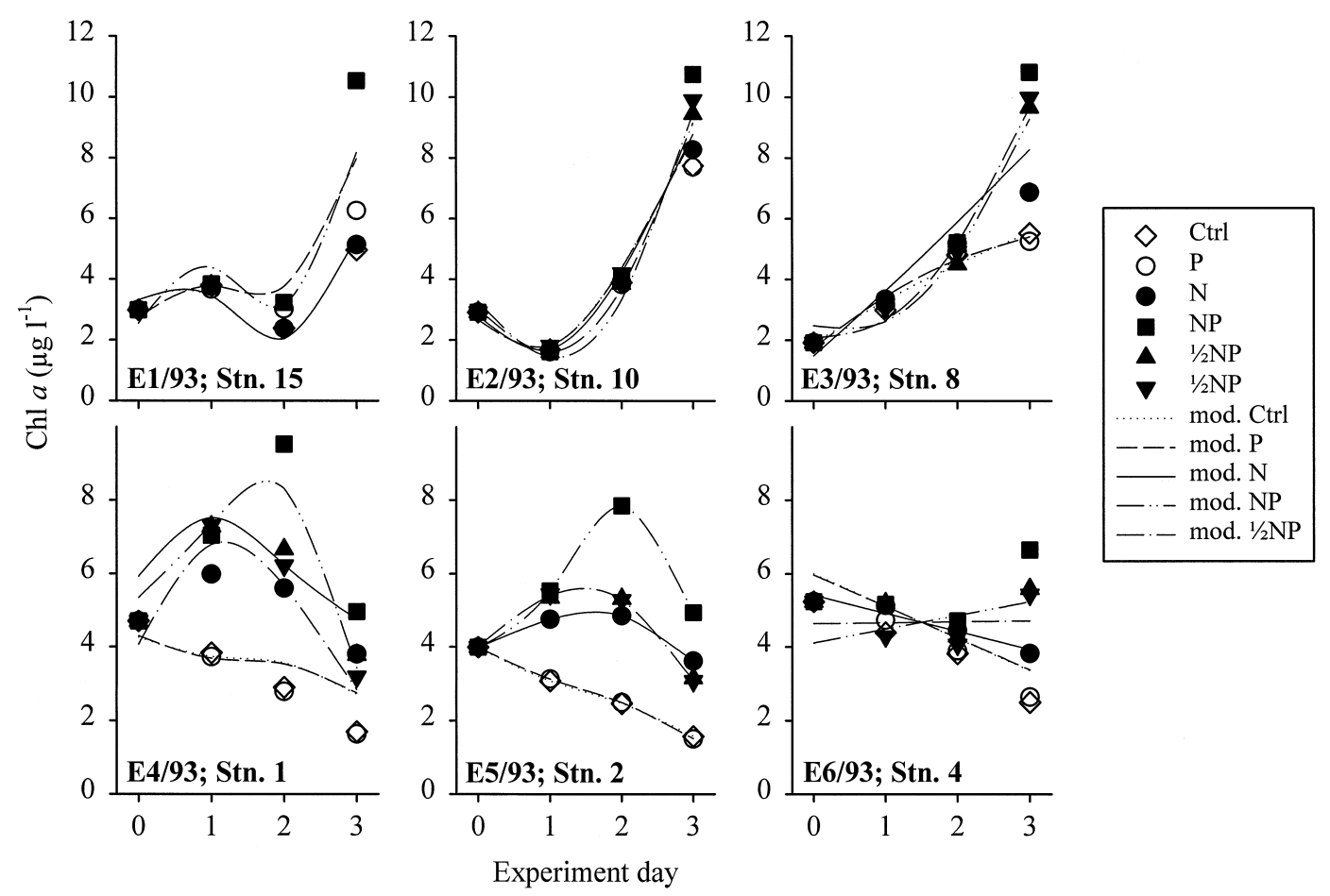

Fig. 10. Temporal development of chl $a$ and simulations (lines) by polynomial regression models in the nutrient enrichment experiments carried out in the Gulf of Riga in late summer 1993. For the location of the stations and times for conducting the experiments, see Fig. 1 and Table 2. 

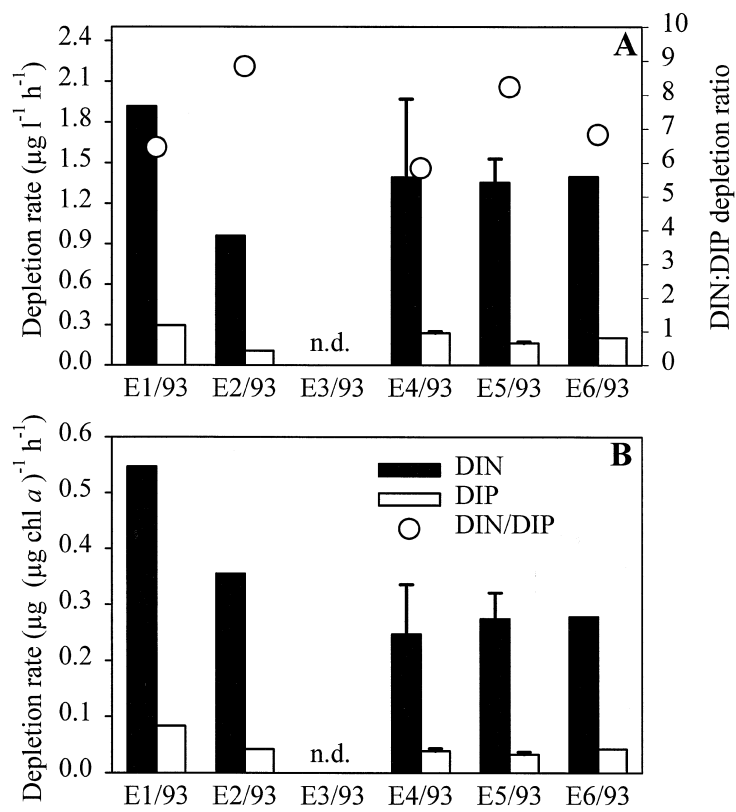

Fig. 11. Apparent depletion rates and ratios (A) and chlorophyll $a$ specific depletion rates (B) of ammonium (DIN) and phosphate (DIP) in the experimental units with full nutrient additions (Unit 4) in late summer 1993. Rates have been calculated from the decrease of inorganic nutrients during the period of 2 days; initial ( $0-1$ day) rates exceeding this are shown as error bars.

significantly higher than those of the others, thus indicating co-limitation. Rather similar response was obtained from the station nearby (E3/93 at Stn. 8), but there the effect of $\mathrm{N}$ was also significant and $\mathrm{N}$ limitation was obvious. Next experiments (E4/93 and E5/93) were carried out at the Irbe Strait area, and they clearly indicated $\mathrm{N}$ limitation; although NP additions gave the highest responses. The last experiment in the northern Gulf (E6/93) also indicated N limitation, although the case was not as obvious as in the previous experiments.

Nutrient depletion rates were almost equal for all experiments (Fig. 11), and the $\mathrm{N} / \mathrm{P}$ depletion ratios (w:w) were relatively constant (range 6.4-8.5) and close to the Redfield ratio. When normalized against chl $a$, the highest depletion rates were obtained from the experiment at the southern Gulf (E1/93). Experiments at the Irbe Strait region (E4/93 and E5/93) showed somewhat higher depletion rates at the beginning of the experiment than when calculated for the period of 2 days.

Ammonium stimulation of $\mathrm{PO}_{4}-\mathrm{P}$ depletion was moderate in the southern Gulf (E1/93) and in the outer Irbe Strait (E4/93) (Table 4). In the other experiment at the Irbe Strait region (E5/93), $\mathrm{PO}_{4}-\mathrm{P}$ was practically not taken up at all in the unit with single $\mathrm{P}$ addition, while in the combined addition unit the depletion was comparable to the other experiments, thus causing high ammonium stimulation of $\mathrm{PO}_{4}-\mathrm{P}$ depletion. In all experiments, except in the

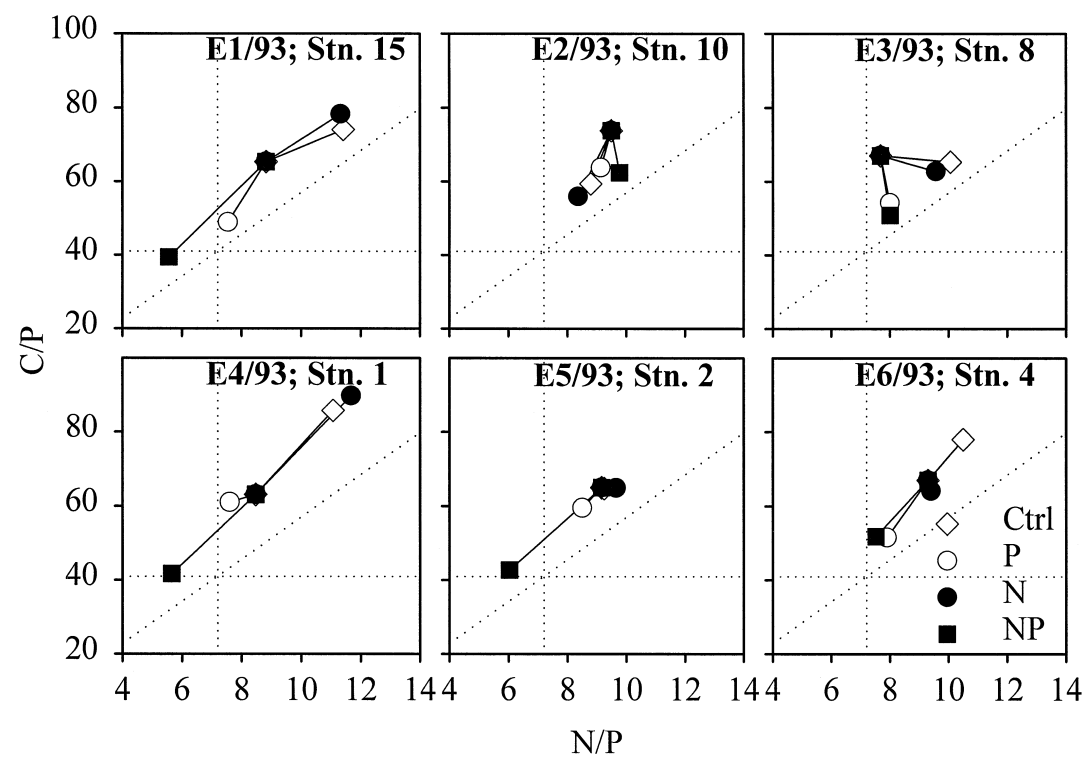

Fig. 12. Trajectories of particulate nutrient ratios in the experiments in late summer 1993. 
central Gulf (E2/93), phosphate stimulation of $\mathrm{N}$ depletion was notable.

As a general feature in all experiments in 1993, particulate $\mathrm{N}$ concentrations increased also in the units without $\mathrm{NH}_{4}-\mathrm{N}$ addition (data not shown), as external available ammonium was utilized. Consequently, in the southern Gulf (E1/93) particulate $\mathrm{N} / \mathrm{P}$ ratio increased in both control and $\mathrm{N}$ addition units (Fig. 12). In the experiments at the central Gulf (E2/93 and E3/93), the changes in particulate nutrient ratios were only slight, and actually not towards balanced Redfield ratio of all elements. In contrast to all the other experiments, $\mathrm{N} / \mathrm{P}$ ratio increased somewhat also in the unit with combined nutrient addition. In the experiments at the Irbe Strait area (E4/93 and $\mathrm{E} 5 / 93$ ), particulate $\mathrm{C} / \mathrm{P}$ and $\mathrm{N} / \mathrm{P}$ ratios in the combined addition unit moved towards the Redfield ratio. In the former experiment, impoverishment of $\mathrm{P}$ was noted in control and unit with single $\mathrm{N}$ addition.

\section{Discussion}

\subsection{Experimental setup for evaluation of phytoplank- ton nutrient limitation}

Nutrient limitation of phytoplankton can be evaluated using many different approaches. The external nutrient concentrations and ratios do not necessarily reflect the actual limitation patterns as nutrients can be supplied through remineralization processes and be stored in intracellular reserves (e.g., Andersen et al., 1991). Therefore, nutrient limitation has been assessed by nutrient content of the cells, nutrient uptake rates, using physiological indicators (e.g., Zevenboom, 1986; Sakshaug and Olsen, 1986; Hecky and Kilham, 1988; Granéli et al., 1990; Graziano et al., 1996) or simply using growth experiments where one or more potentially limiting nutrients are supplied in excess (discussed, e.g., in Hecky and Kilham, 1988). In nutrient enrichment bioassays the system under examination can range from cultured algae to natural water bodies. As pointed out by Hecky and Kilham (1988), the increase of naturalness of the system will decrease the possibility to control the experimental conditions and thus clear results are hard and laborious to obtain. In contrast, the results from experiments with test organisms, like algal cultures, are not necessarily representative for complex natural systems. Our choice for the nutrient limitation studies in the Gulf of Riga was an approach somewhere between these two extremes. The experimental units with the size of 61 allowed to include main components of natural planktonic system, from viruses to mesozooplankton, and the duration of 3 days can be considered short enough to avoid major unwanted "bottle effects".

The factorial experiment design (Khuri and Cornell, 1987) we used is not a common one. In the simplest design with 2 factors at two levels (design $2^{2}$ ), one ends up with 4 experimental units, but if experimental error estimate is desired, all units must be replicated. To reduce the number of units, and labor needed in harsh field conditions, without losing the experimental error estimate or the orthogonal factorial design, we applied the basic $2^{2}$ design with center point replication. Experimental error was then derived from the two central units. The analysis of log-transformed chl $a$ responses from the center units revealed that the relative experimental error was rather constant and small, actually very close to the error of the chl $a$ measurement (see Fig. 3).

Statistical analyses of the chl $a$ responses were carried out with two independent methods. In the polynomial regression analysis, observed variance in the particular experiment is decisive. The ability of the model to explain variability in the observed data will decrease as the error increases, assuming, of course, some constant significance level. Thus in the cases with (randomly) large experimental errors, some rather apparent effects can be determined as insignificant. As an example, in the experiment E3/94, where the polynomial model showed only two significant regression coefficients, the decrease of experimental error by slightly adjusting the chl $a$ responses in 1/2NP units for day 3 (instead of 5.38 and $5.63 \mu \mathrm{g} \mathrm{chl} a 1^{-1}$, values of 5.38 and $5.55 \mu \mathrm{g}$ chl $a 1^{-1}$ are used) produced additional six significant regression coefficients and the response for NP addition was evident also by the model fit. In the other statistical method applied, the experimental error is considered constant from one experiment to another. This might represent a slight simplification, as the incidental developments of different phyto- 
plankton communities are obvious and dependent of the overall stability of the food-web structure and species interactions. Examination of the replicate units from all of our experiments revealed, however, the small and constant experimental error, although the studied phytoplankton systems had very different characters.

Both the nutrient levels and ratios we used have a sound base. Rather similar inorganic nutrient concentrations can be found in the Gulf of Riga, in the spring bloom initiation period (see Tamminen and Seppälä, 1999). Inorganic N/P ratio differs somewhat from the traditional Redfield ratio of 7.2, but indeed our studies revealed that the nutrient depletion ratio, at nutrient replete situations, was often lower than the Redfield ratio and closer to 4 (w:w, see Figs. 5, 8 and 11).

\subsection{Experimental nutrient limitation patterns during different seasons at various locations}

At the spring bloom phase in the Gulf of Riga, phytoplankton was not limited by external $\mathrm{N}$ or $\mathrm{P}$ as high amounts of nitrate and phosphate were available (see Table 2). The decline of water column chl $a$ concentrations and phytoplankton biomass (mainly diatoms) between two cruises separated by 4 days (see Table 2) was, however, an indication of the presence of some other controlling factors. The effect of grazing was rather low at that time, as demonstrated by carbon flow model (Donali et al., 1999), and grazing did apparently not control the algal biomass. Tamminen and Seppälä (1999) found very high chl $a$ values in the deeper layers during the second spring cruise, and one week later Olli and Heiskanen (1999) noted that diatoms contributed most of the settling material and the phytoplankton community at the southern Gulf was dominated by dinoflagellates. It seems obvious that the bulk of diatom cells sedimented out of the mixed layer during and after our cruise and were replaced by dinoflagellates. The reason for such a succession remains obscure, but Olli and Heiskanen (1999) suggested that diatoms were controlled by water column stability. Indication of a diatom-dinoflagellate succession was also obtained in two experiments (E4/95 and E5/95) where the proportion of dinoflagellates from total phytoplankton biomass increased during study period.

Silicate limitation of phytoplankton towards the end of the spring bloom in the Gulf of Riga has been suggested by Yurkovskis and Mazmachs (1996). Since 1991, they have found very low spring concentrations, approaching zero values after the spring bloom period. In spring 1996, using algal tests, Maestrini et al. (1997) did not find any effect of silicate. The species they used, however, have very low requirements for this element. Further, Maestrini et al. (1997) concluded that southeastern part of the Gulf influenced most by the river outflow is P-limited in mid-spring, while in later spring-early summer, it changed towards co-limitation by $\mathrm{N}$ and $\mathrm{P}$. The area outside the river plume was considered mostly $\mathrm{N}$ limited for the whole period. $\mathrm{N}$ or $\mathrm{P}$ limitation in the early spring situation is, however, not apparent for natural algal assemblages as high inorganic concentrations prevail, especially in the river plume. The basin-wide examination of inorganic nutrient ratios indicated potential $\mathrm{N}$ limitation of the bloom in later phases, as N/P ratios were well below the Redfield ratio, except in the southern river plume and Irbe Strait (Tamminen and Seppälä, 1999).

Linear decrease of inorganic nutrients during the whole experiment period also suggests that phytoplankton was not limited by nutrients (Zevenboom, 1986). Moreover, phosphate uptake was saturated at the natural concentrations. Addition of energetically favorable $\mathrm{N}$ source $\left(\mathrm{NH}_{4}-\mathrm{N}\right)$, however, increased phosphate depletion in two experiments (Table 4). Thus, phytoplankton was able to utilize $\mathrm{NH}_{4}-\mathrm{N}$, and indeed it was the preferred $\mathrm{N}$ source. In a study in the coastal Gulf of Finland, Tamminen (1995) noted that before the actual spring bloom, phytoplankton is not able to utilize $\mathrm{NH}_{4}-\mathrm{N}$. Already in the early phases of the bloom, however, ammonium was taken up and it inhibited nitrate depletion, like in our experiments in the Gulf of Riga. Nutrient depletion rates were very low, even in the latter experiments (Fig. 5). In the Gulf of Finland, Tamminen (1995)

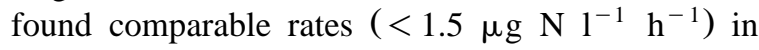
very early phases of the bloom, but when normalized with chl $a$, those were up to 10 times higher. The low biomass specific depletion rates we observed at the time of well developed bloom may indicate the ceased growth of main phytoplankton species, $T$. 
baltica. The increase of chl $a$ specific depletion rates in the course of 4 days may then be attributed to the decrease of unwealthy diatoms through sedimentation, and possibly to the increase of substituting dinoflagellates.

In all experiments during spring, the nutrient depletion occurred below or at the Redfield ratio (Figs. 5 and 13b). This is not, however, necessarily a sign of shortage of phosphorus, as algal species can differ much in their elemental requirements (e.g., Sakshaug and Olsen, 1986; Hecky and Kilham, 1988). Indeed, the trajectories of particulate nutrients (Fig. 6) showed in all cases the decrease of $\mathrm{N} / \mathrm{P}$ and $\mathrm{C} / \mathrm{P}$ ratios during the experimental period, regardless of the manipulation, and thus relative increase of particulate P. Only in the latter experiment in the southern Gulf, impoverishment of $\mathrm{P}$ took place in unit with $\mathrm{NH}_{4}-\mathrm{N}$ addition, as the external $\mathrm{PO}_{4}-\mathrm{P}$ pool became almost depleted.

In mid-June 1994, we found a spatial tendency from clearly N-limited Irbe Strait area to co-limited southern Gulf, via mostly N-limited northern Gulf. Limitation of phytoplankton growth by both $\mathrm{N}$ and $\mathrm{P}$ in early summer stages has been observed also in adjacent areas in the Gulf of Finland (Kivi et al., 1993). Maestrini et al. (1997) concluded that the coastal southern Gulf of Riga was mainly N-limited in early summer, but also the effects of $\mathrm{P}$ were obvious in their study. Basin-wide distribution of inorganic nutrients in the surface indicated general $\mathrm{N}$ limitation in the Gulf of Riga (Tamminen and
Seppälä, 1999). High inorganic $\mathrm{N} / \mathrm{P}$ ratios were, though, found below thermocline, and Tamminen and Seppälä (1999) suggested that mixing events can alter nutrient limitation patterns drastically. They further assumed that high ammonium concentrations at the surface in the southern Gulf were results of deep mixing.

Contradictory to the limitation patterns, N/P depletion ratios increased from the Irbe Strait towards the southern Gulf. It can be hypothesized that in the nutrient depleted natural conditions phytoplankton suffer from the shortage of both $\mathrm{N}$ and $\mathrm{P}$. When both nutrients were supplied, $\mathrm{P}$ was taken up in excess compared to $\mathrm{N}$, as algae are known to store up $\mathrm{P}$ better than N. Development of particulate nutrient ratios supported this and the resulting particulate nutrient ratios approached the Redfield ratio. Also in some units with $\mathrm{NH}_{4}-\mathrm{N}$ addition, but without $\mathrm{PO}_{4}-$ $\mathrm{P}$, the $\mathrm{N} / \mathrm{P}$ ratio decreased. Kononen et al. (1993) noted that in the western Gulf of Finland during low inorganic nutrient concentrations in summer, alkaline phosphatase activity increased significantly in $\mathrm{N}$ supplemented experimental units. Addition of $\mathrm{N}$ may thus increase the utilization of dissolved organic phosphorus, resulting in increase of particulate phosphorus.

Few weeks later, in mid-July, major $\mathrm{N}$ limitation of phytoplankton was established in all experiments and consequently the ambient inorganic $\mathrm{N} / \mathrm{P}$ ratios were very low (see also Tamminen and Seppälä, 1999). High biomass-specific nutrient depletion rates,
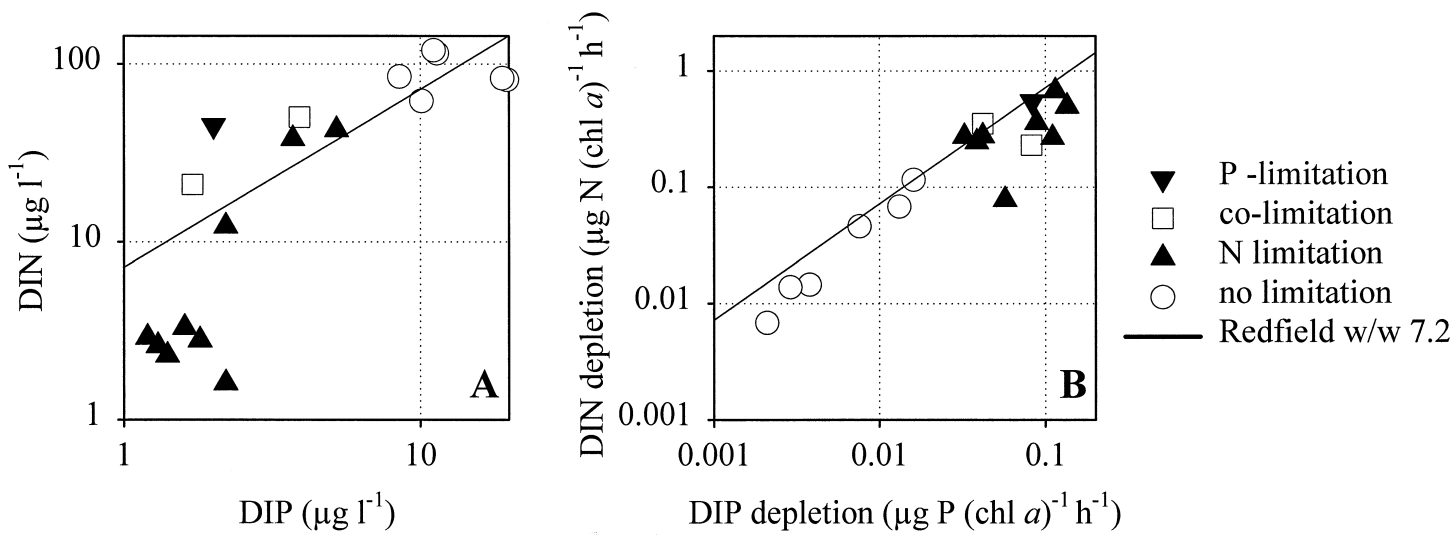

Fig. 13. Scatterplots of initial inorganic nutrient concentrations (A), and chl $a$ specific nutrient depletion rates in experiments (B), and their relationships to nutrient limitation revealed by the enrichment experiments. 
and especially fast depletion of $\mathrm{NH}_{4}-\mathrm{N}$ in nutrient replete units, indicated high nutrient deficiency. Inorganic $\mathrm{N} / \mathrm{P}$ depletion ratios were higher than in preceding experiments, but still well below the Redfield ratio. Although the $\mathrm{N} / \mathrm{P}$ ratio of particulate matter had slightly decreased, affinity for $\mathrm{P}$ was high. While the chl $a$ responses showed $\mathrm{N}$ limitation in all experiments, stimulations of $\mathrm{N}$ or $\mathrm{P}$ depletion by the addition of the other nutrient indicated some level of co-limitation.

Kivi et al. (1993) found, in a successional study in the Gulf of Finland, a shift from co-limitation towards major $\mathrm{N}$ limitation to occur in mid-July. In a recent study, Põder and Jaanus (1997) also suggested that the Irbe Strait area is N-limited during summer, though only nitrate and phosphate were measured. The recent increase of cyanobacterial blooms in the Gulf of Riga has been connected to potential changes in the nutrient ratios (Balode, 1994; Kahru et al., 1994). Nitrogen-fixing cyanobacteria are favored by high temperatures and low inorganic $\mathrm{N} / \mathrm{P}$ ratio (e.g., Wallström, 1988), thus by the conditions which occurred in our study site in mid-July 1994. The microphytoplankton was eventually dominated by A. flosaquae, though the contribution of pico-sized algae was also high (Seppälä and Balode, 1999). The relative amount of particulate $\mathrm{N}$ was highest in the southern Gulf, but it cannot be concluded whether it was risen by nitrogen-fixing cyanobacteria.

Some evidence of vertical migration of phytoplankton, in our study area, was obtained in preceding weeks and during our study period (Seppälä and Balode, 1998; Olli, 1999). Enclosing the natural community in a bottle will thus cease the possible night-time exploitation of deeper water stratum nutrients. That may, partly, explain the decrease of chl $a$ in the control and P units. More obviously, decrease of chl $a$ reflects increased overall irradiance levels. This was also supported by increasing POC/chl $a$ ratio (data not shown).

Tamminen and Seppälä (1999) suggested that deep mixing in the late summer-autumn period in 1993 introduced significant amounts of nutrients from the deep layers into surface. Increase of the mixing depth in late summer 1993, and thus decrease of the mean light availability in the mixed layer, evidently decreased the utilization of nutrients by phytoplankton. Donali et al. (1999) noted that at the time the plankton system was net heterotrophic. As a result, high amounts of ammonium were found in the whole water column. Consequently, clear $\mathrm{P}$ limitation of phytoplankton was found in the southern Gulf (E1/93), while the central Gulf (E2/93) was limited both by $\mathrm{N}$ and $\mathrm{P}$. Despite the elevated $\mathrm{NH}_{4}-\mathrm{N}$ concentrations, other experiments indicated major $\mathrm{N}$ limitation. Stimulations of $\mathrm{N}$ depletion by $\mathrm{PO}_{4}-\mathrm{P}$ are, however, a sign of some degree of co-limitation.

The late summer period was the only season when nutrient depletion ratios were close to the Redfield ratio. Whether the differences in the depletion ratios between seasons reflects the divergence in elemental needs of the phytoplankton is not known. In 1993, the uptake of ambient, non-added, $\mathrm{NH}_{4}-\mathrm{N}$ caused evidently the increase of PON also in the control and $P$ units. In two cases (E2/93 and E3/93), the particulate nutrient ratios in units with combined additions did not turn towards balanced nutrient ratios (Redfield), but indicated storing of N. In other experiments, the changes in the particulate nutrient ratios, again, showed binding of $\mathrm{P}$ in excess into particulate matter.

\subsection{Comparison of nutrient limitation patterns, am- bient nutrient concentrations and nutrient uptake ratios}

Although the ambient nutrient concentrations do not necessarily reflect the actual nutrient limitation, we found quite evident relationships between them and the experimental limitation patterns (Fig. 13a). The only actual case with $\mathrm{P}$ limitation $(\mathrm{E} 1 / 93)$ took place when high $(\mathrm{N} / \mathrm{P} 22.6, \mathrm{w}: \mathrm{w})$ inorganic $\mathrm{N} / \mathrm{P}$ ratios prevailed. Two experiments considered as colimited (E2/93 and E3/94) showed the second and third highest ratios (N/P 12.9 and 12.4, respectively). The rest of the summer experiments can be considered as mainly or only $\mathrm{N}$-limited, and the respective $\mathrm{N} / \mathrm{P}$ ratios were below 10.5. Thus, in few cases when the ratio was well above the Redfield ratio, the experiments showed $\mathrm{N}$ limitation. It must also be noted that for these particular experiments (E3/93 and E6/93) in the central or northern Gulf, the $\mathrm{N} / \mathrm{P}$ depletion ratios were also high, indicating potentially high $\mathrm{N}$ needs. The experiments carried out in spring are considered not to be limited by nutrients, and they can be found in the upper right 
corner in the DIN vs. DIP plot (Fig. 13a). Nutrient depletion ratios, in units with full nutrient additions, do not show similar relationships with the limitation patterns (Fig. 13b). Obviously, $\mathrm{P}$ will be taken up in excess when possible, and the resulting depletion ratio does then not reflect the actual limitation. Further, the Redfield ratio represents an average elemental composition of mixed algal populations, and it is well documented that $\mathrm{N} / \mathrm{P}$ requirements vary among algal species (e.g., Sakshaug and Olsen, 1986). Strikingly, in all cases but two, the depletion ratio was below the Redfield ratio. In spring it averaged 5, in mid-June 2.2, in mid-July 4.6 and in late summer 7.2.

\subsection{Conclusions}

Earlier conclusions on the strict $\mathrm{P}$ limitation of phytoplankton in the whole Gulf of Riga (Nehring et al., 1987; Yurkovskis et al., 1993) seems not to be valid any longer, as agreed recently by many authors (e.g., Yurkovskis and Mazmachs 1996; Põder and Jaanus 1997; Maestrini et al., 1997; Tamminen and Seppälä, 1999). Whether there have been some recent changes in the limitation patterns is not a subject of this study. Our experimental results indicated that $\mathrm{N}$ is a major limiting nutrient, alone, or with $\mathrm{P}$, in the summer situations in the main basin of the Gulf of Riga. In times of deep mixing, the southern Gulf was more P or co-limited. In spring we could not find any nutrient limitation, but the results of a parallel study (Tamminen and eppälä, 1999) indicated potential $\mathrm{N}$ limitation of the bloom in main basin. Generally, the nutrient limitation patterns in the northern Gulf of Riga and Irbe Strait area seem to be comparable to those observed in the Gulf of Finland (Kivi et al., 1993). The southern Gulf resembles more the situation in the Neva estuary, eastern Gulf of Finland, where deep mixing favors P limitation (Pitkänen and Tamminen, 1995). Obviously, the immediate River Daugava outlet will be more Plimited than other areas.

\section{Acknowledgements}

We thank E. Salminen, M. Sjöblom, M. Pokki and A. Nevalainen for nutrient analyses, and $\mathrm{M}$.
Balode for phytoplankton counts. Valuable comments of two anonymous reviewers are acknowledged. This study is a contribution of the projects 'Pelagic Eutrophication and Sedimentation in the Gulf of Riga' financed by Nordic Council of Ministers and 'PELAG III' (Nitrogen Discharge, Pelagic Nutrient Cycles, and Eutrophication of the Coastal Environment of the Northern Baltic Sea).

\section{References}

Andersen, T., Schartau, A.K.L., Paasche, E., 1991. Quantifying external and internal nitrogen and phosphorus pool, as well as nitrogen and phosphorus supplied through remineralization, in coastal marine plankton by means of a dilution technique. Mar. Ecol. Prog. Ser. 69, 67-80.

Astok, V., Hannus, M., Jaanus, A., 1991. The state of the coastal waters of the Gulf of Riga in the 1980s; general conclusions. Interim Report on the State of the Coastal Waters of the Baltic Sea. Balt. Sea Environ. Proc. 40, 84-87.

Balode, M., 1994. Long-term changes of summer-autumn phytoplankton communities in the Gulf of Riga. In: Guelorget, O., Lefebvre, A. (Eds.), Baltic Sea and Mediterranean Sea. A comparative ecological approach of coastal environments and paralic ecosystems. Montpellier, France, pp. 96-99.

Donali, E., Olli, K., Heiskanen, A.-S., Andersen, T., 1999. Carbon flow patterns in the planktonic food web of the Gulf of Riga, the Baltic Sea: a reconstruction by the inverse method. J. Mar. Syst. 23, 251-268 (this issue).

Draper, N.R., Smith, H., 1981. Applied Regression Analysis. Wiley, New York, 702 pp.

Granéli, E., Wallström, K., Larsson, U., Granéli, W., Elmgren, R., 1990. Nutrient limitation of primary production in the Baltic Sea area. Ambio 19, 142-151.

Graziano, L.M., Geider, R.J., Li, W.K.W., Olaizola, M., 1996. Nitrogen limitation of North Atlantic phytoplankton: analysis of physiological condition in nutrient enrichment experiments. Aquat. Microb. Ecol. 11, 53-64.

Hecky, R.E., Kilham, P., 1988. Nutrient limitation of phytoplankton in freshwater and marine environments: a review of recent evidence on the effects of enrichment. Limnol. Oceanogr. 33, 796-822.

Kahru, M., Horstmann, U., Rud, O., 1994. Satellite detection of increased cyanobacteria blooms in the Baltic Sea: natural fluctuations or ecosystem change. Ambio 23, 469-472.

Khuri, A.I., Cornell, J.A., 1987. Response Surfaces. ASQC Quality Press, New York, 405 pp.

Kivi, K., Kaitala, S., Kuosa, H., Kuparinen, J., Leskinen, E., Lignell, R., Marcussen, B., Tamminen, T., 1993. Nutrient limitation and grazing control of the Baltic plankton community during annual succession. Limnol. Oceanogr. 38, 893-905.

Kononen, K., Lahdes, E., Grönlund, L., 1993. Physiological and community responses of summer plankton to nutrient manipulation in the Gulf of Finland (Baltic Sea) with special reference to phosphorus. Sarsia 78, 243-253. 
Lignell, R., Kaitala, S., Kuosa, H., 1992. Factors controlling phyto- and bacterioplankton in late spring on a salinity gradient in the northern Baltic. Mar. Ecol. Prog. Ser. 84, 121-131.

Maestrini, S.Y., Balode, M., Béchemin, C., Purina, I., Vérité, C., 1997. Nutrients limiting the algal growth potential (AGP) in the Gulf of Riga, eastern Baltic Sea, in spring and early summer 1996. La Mer 35, 49-68.

Nehring, D., Frtebjerg, G., Alenius, P., Astok, V., Fonselius, S., Hannus, M., Tervo, V., Trzosinska, A., Tulkki, P., Yurkovskis, A.K., 1987. Nutrients. First periodic assessment of the state of the marine environment of the Baltic Sea area, 1980-1985; background document. Balt. Sea Environ. Proc. 17B, 35-81.

Ojaveer, E. (Ed.), Ecosystem of the Gulf of Riga Between 1920 and 1990. Estonian Academy Publishers, 277 pp.

Olli, K., 1999. Diel vertical migration of phytoplankton and heterotrophic flagellates in the Gulf of Riga. J. Mar. Syst. 23, $145-163$ (this issue).

Olli, K., Heiskanen, A.-S., 1999. Seasonal stages of phytoplankton community structure and sinking loss in the Gulf of Riga. J. Mar. Syst. 23, 165-184 (this issue).

Pitkänen, H., Tamminen, T., 1995. Nitrogen and phosphorus as production limiting factors in the estuarine waters of the eastern Gulf of Finland. Mar. Ecol. Prog. Ser. 129, 283-294.

Põder, T., Jaanus, A., 1997. Nutrient concentrations and phytoplankton variables in the Gulf of Riga and Baltic Proper water mixing area: an attempt to test the dichotomy of limiting nutrient. In: Ojaveer, E. (Ed.), Proceedings of the 14th Baltic Marine Biologists Symposium. Estonian Academy Publishers, Tallinn, pp. 223-226.

Sakshaug, E., Olsen, Y., 1986. Nutrient status of phytoplankton blooms in Norwegian waters and algal strategies for nutrient competition. Can. J. Fish. Aquat. Sci. 43, 389-396.

Seppälä, J., Balode, M., 1998. The use of spectral fluorescence methods to detect changes in the phytoplankton community. Hydrobiologia 363, 207-217 (this issue).

Seppälä, J., Balode, M., 1999. Spatial distribution of phytoplankton in the Gulf of Riga during spring and summer stages. J. Mar. Syst. 23, 51-67 (this issue).
Stipa, T., Tamminen, T., Seppälä, J., 1999. On the creation and maintenance of stratification in the Gulf of Riga. J. Mar. Syst. 23, 27-49 (this issue).

Tamminen, T., 1995. Nitrate and ammonium depletion rates and preferences during a Baltic spring bloom. Mar. Ecol. Prog. Ser. 120, 123-133.

Tamminen, T., Seppälä, J., 1999. Nutrient pools, transformations, ratios, and limitation in the Gulf of Riga, the Baltic Sea, during four successional stages. J. Mar. Syst. 23, 83-106, (this issue).

Tamminen, T., Kaitala, S., Kivi, K., Kuparinen, J., 1985. Response of a planktonic brackish water community to single and combined additions of ammonium and phosphate in a factorial mesocosm experiment. In: Gray, J.S., Christiansen, M.E. (Eds.), Marine Biology of Polar Regions and Effects of Stress on Marine Organisms. Wiley, New York, pp. 363-378.

Wallström, K., 1988. The occurrence of Aphanizomenon flosaquae (Cyanophyceae) in a nutrient gradient in the Baltic. Kieler Meeresforsch., Sonderh. 6, 210-220.

Wintermans, J.F.G.H., De Mots, A., 1965. Spectrophotometric characteristics of chlorophylls $a$ and $b$ and their phaeophytins in ethanol. Biochem. Biophys. Acta 109, 448-453.

Yurkovskis, A., Mazmachs, M., 1990. Gulf of Riga. Second periodic assessment of the state of the marine environment of the Baltic Sea, 1984-1988; background document. Balt. Sea Environ. Proc. 35B, 147-148.

Yurkovskis, A., Mazmachs, M., 1996. Hydrochemistry. Third periodic assessment of the state of the marine environment of the Baltic Sea, 1989-1993; background document. Balt. Sea Environ. Proc. 64B, 64-65.

Yurkovskis, A., Wulff, F., Rahm, L., Andruzaitis, A., RodriguezMedina, M., 1993. A nutrient budget of the Gulf of Riga; Baltic Sea. Estuarine Coastal Shelf Sci. 37, 113-127.

Zevenboom, W., 1986. Ecophysiology in nutrient uptake, photosynthesis and growth. In: Platt, T., Li, W.K.W. (Eds.), Photosynthetic Picoplankton, Can. Bull. Fish. Aquat. Sci. 214pp. $391-422$. 